\title{
Bioactive Natural Products against Prostate Cancer: Mechanism of Action and Autophagic| Apoptotic Molecular Pathways
}

Authors

Affiliation
Katerina Gioti, Roxane Tenta

Department of Nutrition and Dietetics, Harokopio University, Athens, Greece
Key words

- natural products

- prostate cancer

- autophagy

apoptosis received August 7, 2014

revised February 9, 2015

accepted February 16, 2015

\section{Bibliography}

DOI http://dx.doi.org/ 10.1055/s-0035-1545845

Published online April 15, 2015

Planta Med 2015; 81: 543-562

(c) Georg Thieme Verlag KG

Stuttgart · New York .

ISSN 0032-0943

\section{Correspondence}

Roxane Tenta, MSc, PhD

Harokopio University

Department of Nutrition and

Dietetics

70 El. Venizelou Str.

17671 Athens

Greece

Phone: + 302109549153

Fax: + 302109577050

rtenta@hua.gr

\section{Abstract \\ $\nabla$}

Prostate cancer is one of the leading causes of death worldwide for men. There is increasing evidence that diet and lifestyle play a crucial role in prostate cancer biology and tumorigenesis. Due to the fact that conventional chemotherapy is not adequately effective against prostate cancer and has severe side effects, numerous in vitro studies have been conducted in order to identify the potent cytotoxic or chemopreventive activity of nat-

\section{Introduction}

\section{$\nabla$}

Prostate cancer (PCa) is one of the most common malignancies in men and a leading cause of death worldwide for men. Taking into consideration that chemotherapy has severe side effects and usually a poor outcome, there is an intensive need for the development of safer and more effective agents. Since plants have been used by traditional medicine for the treatment of various diseases, in the last decades, many natural products have been isolated from plants and tested for their tumor selectivity and cytotoxic efficacy. Several of these naturally occurring compounds have been found to inhibit PCa growth and metastasis and are thus a promising approach for the treatment of this malignancy. Laboratory studies in different in vitro and in vivo systems have shown that these natural products modulate cellular processes, exhibit chemopreventive and/or chemotherapeutic effects, and induce apoptosis and autophagy. Accordingly, the antiproliferative and autophagic effects of nontoxic dietary agents could be of additional significance for the prevention, control, and management of PCa, specifically for the advanced and androgen-independent stage of the malignancy [1-3]. As there is increasing data on how natural compounds interfere with diverse molecular pathways in cancer cells, this review dis- urally occurring compounds and their respective molecular mechanisms of action. In this context, many natural compounds isolated from plants have been found to inhibit cancer growth and to induce cell cycle arrest, suppress angiogenesis, and promote apoptotic or autophagic cell death. Therefore, in this article, the most promising bioactive natural products and their respective mechanisms of action for the prevention or/and treatment of prostate cancer are presented.

cusses the mechanism of action of bioactive natural products in the field of PCa and emphasizes the implicated molecular pathways of apoptosis and autophagy as important processes that control cellular homeostasis and that have been highlighted as promising targets for novel cancer therapies.

\section{Apigenin}

Apigenin (4',5,7-trihydroxyflavone) is a flavone found in plants of the Asteraceae family, such as Anthemis sp., and many fruits and vegetables [4]. Apigenin has been tested in various types of cancer cell lines (breast, colon, liver, lung) showing promising results [5]. In prostate cancer in particular, apigenin administered in various concentrations $(1-20 \mu \mathrm{M})$ for 24,48 , and $72 \mathrm{~h}$ not only causes $\mathrm{G} 1$ cell cycle arrest both in androgen-dependent (LNCaP) and -independent (DU145 and PC-3) PC cell lines through the decreased expression of cyclins D1, D2, and E, but also induces apoptosis through a shift in the Bax/Bcl-2 ratio $[6,7]$. Further studies in PC-3 cells have also demonstrated that apigenin $(5-40 \mu \mathrm{M})$, delivered for $24 \mathrm{~h}$, suppresses cell proliferation and induces apoptosis by inhibiting IGF-IGF-IR signaling and inactivating the PI3k/Akt pathway [8]. Apigenin 
treatment of PC-3M cells ( $25 \mu \mathrm{M}$ for $16 \mathrm{~h}$ ) also prevents cell motility and invasion through a disruption of the actin cytoskeleton organization and inhibition of FAK/scr signaling [9]. Apigenin is also a mediator of epigenetic events, when administered at similar concentrations $(20-40 \mu \mathrm{M})$, as it inhibits class I HDACs both in PC-3 and 22Rv1 cells [10]. In 22Rv1 cells, induction of apoptosis is attributed to ROS generation, which subsequently triggers transcriptional, p53-dependent and -independent, pathways [11]. The antiangiogenetic potential of apigenin is also demonstrated in PC-3, LNCaP, and C4-2B cells and is attributed to a decreased production of vascular endothelial growth factor (VEGF) leading to the inhibition of cancer progression and metastasis [12]. Finally, in vivo studies have shown that apigenin causes growth inhibition of 22Rv1 and PC-3 tumor xenografts in athymic nude mice [13], whereas in TRAMP mice, apigenin suppresses cancer progression [14].

\section{Artemisinin and Derivatives}

$\nabla$

Artemisinin $\quad(3 R, 5 \mathrm{a} S, 6 R, 8 \mathrm{a} S, 9 R, 12 S, 12 \mathrm{a} R)$-octahydro-3,6,9-trimethyl-3,12-epoxy-12H pyrano[4,3-j]-1,2-benzodioxepin-10

$(3 \mathrm{H})$-one is a sesquiterpene lactone and a naturally occurring component of Artemisia annua (Asteraceae) [15]. It is a potent antimalarial compound that was shown to have antiproliferative effects on a number of human cancer cell lines. Artemisinin treatment ( $300 \mu \mathrm{M}$ for $48 \mathrm{~h}$ ) triggers G1 cell cycle arrest of LNCaP human prostate cancer cells due to the transcriptional downregulation of CDK4 expression caused by a disruption of Sp1 interactions with the CDK4 promoter [16]. Furthermore, artesunate (ART), a semisynthetic derivative of artemisinin, is found to cause G2/M cell cycle arrest in PC-3 cancer cells [17]. Other studies demonstrated that dihydroartemisinin (DHA), another derivative of artemisinin, reduces cell viability in a time- (30 $\mu \mathrm{M}$ for 24,48 , and $72 \mathrm{~h}$ ) and dose-dependent (10-50 $\mu \mathrm{M}$ for $24 \mathrm{~h})$ manner in androgen-dependent (LNCaP) and -independent (DU145 and PC-3) cells by the activation of caspases 8 and 9, suggesting that DHA is involved both in the extrinsic and intrinsic pathways of apoptosis. Finally, DHA and the artemisin dimers ON-2Py and 2Py cause a dose-dependent decrease in the proliferation of LNCaP and PC-3 cells through growth arrest $[18,19]$.

\section{Baicalin-Baicalein}

$\nabla$

7-D-glucuronic acid-5,6-dihydroxyflavone is a flavone isolated from Scutellaria baicalensis (Lamiaceae) which is converted to baicalein, in vivo [20]. Baicalin inhibits cell proliferation of various cancer cell lines (bladder, bone, breast, colon, liver) and exerts its cytotoxic/cytostatic effect through the induction of apoptosis in DU145, PC-3, LNCaP, and CA-HPV-10 prostate cancer cell lines when administered at concentrations of $150 \mu \mathrm{M}$ or above for 2-4 days [21]. A study in LNCaP cells revealed that baicalin increases the expression of cyclin-dependent kinase inhibitor [p27 (kip1)] and causes G1 cell cycle arrest. Similar results are found for baicalein [22]. Baicalin at doses of $50 \mu \mathrm{M}$ and $125 \mu \mathrm{M}$ also induces G1 arrest and apoptosis in DU145 cells through the inhibition of bcl-2, loss of Bax, and upregulation of Fas [23]. In PC-3 cells, baicalein overcomes TRAIL resistance by upregulating DR5. Finally, both baicalin and baicalein prevent angiogenesis and reduce tumor volume in xenograft models receiving different doses of baicalein (10-40 $\mathrm{mg} / \mathrm{kg}$ per day) for 28 days.

\section{Berberine}

$\nabla$

Berberine (5,6-dihydro-9,10-dimethoxybenzo[g]-1,3-benzodioxolo[5,6-a]quinolizinium) is an isoquinoline alkaloid derived from the plants of the genus Berberis (Berberidaceae) [24]. Treatment of DU145, PC-3, and LNCaP cells with berberine leads to inhibition of cell proliferation combined with G1 cell cycle arrest in a dose- (10-100 $\mu \mathrm{M})$ and time-dependent (24-72 h) manner, without affecting normal human prostate epithelial cells. The suggested molecular mechanisms refer to the inhibition of the expression of cyclins D1, D2, and E and cyclin-dependent kinase (Cdk) 2, Cdk4, and Cdk6 proteins, the increased expression of the Cdk inhibitory proteins (Cip1/p21 and Kip1/p27), and the enhanced binding of Cdk inhibitors to Cdks. Berberine induces cell death of cancer cells via modulations of the Bax/Bcl-2 ratio, disruption of the mitochondrial membrane potential, and activation of poly(ADP-ribose) polymerase and caspases [25]. Low concentrations of berberine (less than $50 \mu \mathrm{M}$ ) in RM-1 cells trigger G1 arrest associated with the activation of the p53-p21 cascade, whereas higher concentrations (over $50 \mu \mathrm{M}$ ) of berberine cause G2/M arrest. Studies in LNCaP xenografts in nude mice revealed that berberine delivered at $5 \mathrm{mg} / \mathrm{kg} /$ day inhibits tumor growth due to a reduction in AR expression [26]. Finally, berberine (at doses of $30 \mu \mathrm{M}$ and $50 \mu \mathrm{M}$ ) enhances the radiosensitivity of human prostate cancer cells as it interferes with MAPK/caspase-3 and ROS pathways and inhibits the expression of HIF-1alpha and VEGF [27].

\section{Betulinic Acid}

$\nabla$

Betulinic acid [(3beta-hydroxy-20(29)-lupaene-28-oic acid] (BA) is a pentacyclic triterpene derived from the bark of Betula papyrifera (Betulaceae) [28]. BA (1-5 $1 \mathrm{M})$ was firstly shown to trigger apoptosis and antiangiogenic responses in LNCaP cells and then in xenograft models when delivered at doses of 10 and $20 \mathrm{mg} /$ $\mathrm{kg} /$ day every second day for 14 days by decreasing the expression of the anti-apoptotic proteins, survivin and VEGF, caused by degradation of the transcription factors specificity proteins Sp1, Sp3, and Sp4 [29]. Treatment of PC-3 cells with BA (10 $\mu \mathrm{M}$ and $20 \mu \mathrm{M})$ inhibits TNF $\alpha$-induced activation of NF- $k$ B, which shifts the Bax/ $\mathrm{Bcl}-2$ ratio and leads to cleavage of poly(ADP)ribose polymerase and thus induces apoptosis [30]. Recently, BA was found to inhibit multiple deubiquitinases (DUBs), which results in poly-ubiquitinated protein accumulation, decreased levels of oncoproteins, and increased apoptotic cell death in LNCaP, DU145, and PC-3 cells. BA treatment ( $10 \mathrm{mg} / \mathrm{kg}$ for 15 days) of TRAMP mice results in inhibition of proliferation, tumor growth, and angiogenesis, and lowers the levels of the androgen receptor and cyclin D expression and the induction of apoptosis [31].

\section{Capsaicin}

$\nabla$

Capsaicin (8-methyl- $\mathrm{N}$-vanillyl-6-nonenamide) is a vanilloid isolated from the plants of the genus Capsicum (Solanaceae) [32]. Capsaicin inhibits the growth of PC-3 cells, both in vitro ( $\mathrm{IC}_{50}$ of $20 \mu \mathrm{M})$ and in xenograft models ( $5 \mathrm{mg} / \mathrm{kg}$ ), and stimulates apoptosis through reactive oxygen species generation, dissipation of the mitochondrial inner transmembrane potential, and activation of caspase 3 [33]. Further studies in PC-3 cells reveal that apoptosis is also induced by ceramide accumulation and activation 
of JNK and ERK [34]. Likewise, capsaicin at varying concentrations $(100-500 \mu \mathrm{M})$ triggers apoptosis both in androgen-dependent (LNCaP) and refractory (DU-145) prostate cancer cell lines and is associated with an increase of p53, p21, and Bax, a downregulation of both the prostate-specific antigen (PSA) and AR, and inhibition of proteasome activity [35].

\section{Curcumin}

$\nabla$

Curcumin (diferulolylmethane), a diphenylheptanoid isolated from Curcuma longa (turmeric; Zingiberaceae) [36], was firstly described to induce apoptosis at doses of 5-50 $\mu \mathrm{M}$ in both androgen-dependent and refractory prostate cancers by interfering with the EGF-R signaling pathway [37]. Apoptosis is also prompted by curcumin's interference with Bcl proteins, ROS generation, and the activation of mitochondrial related pathways. In PC-3 cells, the induction of apoptosis is attributed to apoptosisinducing factor (AIF) and caspase-independent mechanisms [38]. Further studies revealed that curcumin decreases the proliferation of prostate cancer cells through the downregulation of the androgen receptor, whereas the activation of caspase-dependent apoptosis is a result of the downregulation of AP-1, NF- $k$ B, cAMP response element-binding protein (CREB), PSA, and cyclin $D$ [39]. In addition, prostate cancer cells are accumulated in the G1 phase by the proteasome-mediated downregulation of cyclin $\mathrm{E}$ and the upregulation of CDKs. In early-stage prostate cancer, curcumin acts as a chemopreventive agent affecting Wnt $/ \beta$-catenin pathways, leading to autophagy [40]. Furthermore, curcumin suppresses glyoxalases, and thus modulates metabolic cellular pathways and acts as a histone acetyltransferase inhibitor [41]. Other studies have shown that curcumin prevents PC angiogenesis and metastasis by interfering with the cell cytoskeleton organization and the VEGF expression, respectively. Studies in DU145 xenografts, when curcumin is administered at doses of $5 \mathrm{mg} / \mathrm{kg}$ thrice a week for four weeks, show that invasion and metastasis suppression by curcumin can also be attributed to a reduction in metalloproteinases expressed by cancer cells [42]. Inhibition of PCa growth combined with a reduction in the metastasis rate caused by curcumin was also found in the first in vivo model tested, LNCaP xenograft in nude mice [43]. Interestingly, several studies have been conducted in order to enhance curcumin delivery to cancer cells through liposomal distribution, curcumin-loaded nanospheres, cellulose nanoparticles, and coloaded lipid-based carriers with promising results [44].

\section{Daidzein}

$\nabla$

Daidzein (4',7-dihydroxyisoflavone) is an isoflavone (steroid glucoside) isolated from soy beans (Glycine max) (Fabaceae) [45] and was firstly found to inhibit LNCaP and PC-3 cell growth. Even though daidzein does not influence the cell cycle of LNCaP and PC-3 cells, it decreases the expression of VEGF and AR genes in both cell lines and elevates the apoptosis percentage of LNCaP cells via the Akt pathway. Daizein has also been found to cause modulations of the cyclin-dependent kinase-related pathway genes and a downregulation of EGF and IGF in LNCaP, PC-3, and DU145 cells [46]. Recent studies show that daizein $(110 \mu \mathrm{M}$ for $48 \mathrm{~h}$ ) can cause epigenetic modifications to DNA, such as the promoter $\mathrm{CpG}$ island demethylation of tumor suppressor genes, thus demonstrating a chemopreventive role [47].

\section{Delphinidin}

$\nabla$

Delphinidin [2-(3,4,5-trihydroxyphenyl)chromenylium-3,5,7triol] is an anthocyanidin (coumaroyl glucoside) mostly isolated from Viola sp. (Violaceae) and Delphinium sp. (Ranunculaceae) and from many pigmented fruits and vegetables [48]. Delphinidin has been shown to induce a dose-dependent $(30-180 \mu \mathrm{M})$ inhibition of cell growth and apoptosis in LNCaP, C4-2, 22Rv1, and PC -3 cells via the inhibition of NFkB signaling and the subsequent activation of caspases. Other studies propose that delphinidin induces cell growth inhibition and apoptosis of human PC-3 cells by inhibition of Notch-1 and/or NF- $k B / P I 3 K$ pathways and Wnt/ $\beta$ catenin signaling [49]. In PC-3 xenografts in athymic nude mice, delphinidin administration ( $2 \mathrm{mg} /$ animal thrice a week) resulted in a significant inhibition of tumor growth [50].

\section{Ellagic Acid}

$\nabla$

Ellagic acid (2,3,7,8-tetrahydroxy-chromeno[5,4,3-cde]chromene-5,10-dione) (EA) is a polyphenolic compound [51] found in various fruits such as blackberries (Rubus sp., Rosaceae), cranberries (Vaccinium sp., Ericaceae), pecans, pomegranates, raspberries and strawberries. Studies in LNCaP cells show that EA can cause DNA damage while it downregulates antiapoptotic proteins, such as silent information regulator 1 (SIRT1), upregulates the tumor suppressor protein p21, and modulates the expression of AIF thus resulting in ROS-mediated and caspase-mediated apoptosis [52]. Recent studies in LNCaP cells also depict the antiangiogenetic effects of EA (at concentrations of 25 and $50 \mu \mathrm{M}$ ) as it decreases the eicosanoid biosynthesis levels and suppresses the HO system. In androgen-independent PC cells, DU145 and PC-3, EA is found to induce cell cycle arrest in the $S$ phase and apoptosis in a dose- (15-60 $\mu \mathrm{mol} / \mathrm{L})$ and time-dependent (24$120 \mathrm{~h}$ ) manner, which is associated with a decrease in cyclin B1 and cyclin D1 levels and caspase-dependent pathways. Finally, EA is shown to confine the invasive potential of PC-3 and rat PC cell lines by interfering with protease activity and decreasing the secretion of matrix metalloproteinase MMP-2 [53].

\section{Epigallocatechin-3-Gallate}

Epigallocatechin-3-gallate $[(2 R, 3 R)-5,7$-dihydroxy-2-(3,4,5-trihydroxyphenyl)chroman-3-yl)3,4,5-trihydroxybenzoate] (EGCG) is a catechin derived mainly from tea (Camellia sinensis, Theaceae) [54]. Studies in LNCaP and DU145 cells have shown that EGCG causes G0/G1 cell cycle arrest and induces apoptosis in a cell-type-specific manner, irrespective of the p53 status of the cells [55]. EGCG treatment upregulates the expression of WAF1/ p21, KIP1/p27, INK4a/p16, and INK4c/p18 and down-modulates the expression of cyclin D1, cyclin E, cdk2, cdk4, and cdk6 proteins while it increases the binding of cyclin D1 toward WAF1/ p21 and KIP1/p27 and decreases the binding of cyclin E toward cdk2 [56]. In particular, EGCG-induced apoptosis in LNCaP cells is mediated through the modulation of p53 and NF- $k$ B expression, subsequent change in the $\mathrm{Bax} / \mathrm{Bcl}-2$ ratio, and activation of capsases 3, 8, and 9 followed by poly (ADP-ribose) polymerase cleavage when administered in $20-80 \mu \mathrm{M}$ for 24,48 , and $72 \mathrm{~h}$ [57]. Other molecular mechanisms involved in the induction of apoptosis refer to the inhibition of COX-2 without affecting COX1 expression, both in LNCaP and PC-3 cells, and ERK1/2 activation 
via an MEK-independent, PI3-K-dependent signaling pathway in PC-3 cells $[58,59]$. In addition, EGCG $(10-60 \mu \mathrm{M})$ antagonizes androgen action at multiple levels, as it suppresses the activation of the agonist-dependent androgen receptor through Sp1-protein and AR-regulated gene transcription, thus resulting in the inhibition of PCa growth. Invasion and migration are also inhibited after EGCG treatment via modulations in VEGF, uPA, angiopoietin 1 and 2, MMP-2, and MMP-9 [60].

Administration of $0.06 \%$ EGCG in TRAMP mice demonstrated that EGCG leads to attenuation of AR and the IGF-1 expression and decreases the MAPK signaling, thus inducing apoptosis without toxicity. Combinational treatment with $1 \mu \mathrm{M}$ EGCG and cisplatin (2.5 or $5 \mu \mathrm{M}$ ) promotes the expression of the proapoptotic splice isoform of caspase 9 in PC-3 cells. Furthermore, oral administration of encapsulated EGCG reduces cell viability and induces apoptosis of DU145 PC cells. Finally, chitosan nanoparticles encapsulating epigallocatechin-3-gallate cause tumor growth inhibition and a reduction of secreted PSA levels [61,62].

\section{Fisetin}

$\nabla$

Fisetin (3,3',4',7-tetrahydroxyflavone) is a flavonol derived from many plants, such as Acacia greggii (Fabaceae) [63], which has been shown to have cytotoxic and cytostatic effects in numerous cancer cell lines (breast, blood, liver, lung, melanoma, ovary, pancreas) [5]. Studies in prostate LNCaP cells revealed that fisetin, when administered at $10-60 \mu \mathrm{M}$ for 24 and $48 \mathrm{~h}$, causes $\mathrm{G} 1$ cycle arrest by downregulating cyclins and cyclin-dependent kinases and triggers both caspase-dependent and -independent apoptotic pathways. Fisetin also decreases AR levels and competes with the AR ligand [64]. In highly metastatic PC-3 cells, fisetin inhibits adhesion, migration, and metastasis by interfering with the NF$\kappa \mathrm{B}$ pathway and by downregulating MMP-2 and MMP-9 [65]. The downregulation of NF- $k \mathrm{~B}$ is accompanied with an increased TRAIL-induced apoptosis in LNCaP, DU145, and PC-3 cells [66]. It is noteworthy that fisetin also induces autophagic cell death through the inhibition of mTOR and PI3K/Akt signaling [67]. In a CWR22Rupsilon1 human xenograft model, a fisetin injection (1 mg/animal) twice weekly was found to suppress tumor growth and reduce PSA levels [64].

\section{Formononetin}

$\nabla$

Formononetin (7-hydroxy-4'-methoxyisoflavone) (FN) is an 0methylated isoflavone acting as a phytoestrogen, which is found in red clover plants (Trifolium pretense, Fabaceae) [45]. FN has been shown to provoke apoptosis in LNCaP and PC-3 cells through the ERK1/2 MAPK-Bax pathway [68]. Further studies in PC-3 cells show that FN-induced apoptosis is associated with the inhibition of the IGF-1/IGF-1R pathway, alterations in the Bax/ Bcl-2 ratio, and modulations of the p38/Akt pathway when delivered at 25,50 , and $100 \mu \mathrm{M}$ for $48 \mathrm{~h}[69,70]$. FN triggers apoptosis in DU145 cells as well through the activation of the mitochondrial apoptotic pathway, which follows the upregulation of RASD1 [71].

\section{Gallic Acid}

$\nabla$

Gallic acid (3,4,5-trihydroxybenzoic acid) (GA) is a polyphenolic constituent of grape (Vitis vinifera, Vitaceae) seed extract [72]. GA prompts a dose- $(10-50 \mu \mathrm{mol} / \mathrm{L})$ and time-dependent (6$24 \mathrm{~h}$ ) growth inhibition and G2/M cell cycle arrest in DU145 cells through DNA damage and an increase of cdc25A/C-cdc2 phosphorylation. GA also results in apoptotic death of PCa cells by triggering the cleavage of caspase-9, caspase-3, and poly (ADP-ribose) polymerase (PARP) as well as by inducing ROS and mitochondria-mediated mechanisms [73]. GA has been shown to cause DNA damage and inhibit the invasion and migration of PC-3 cells in a dose- $(50-200 \mu \mathrm{M})$ and time-dependent (12$48 \mathrm{~h}$ ) manner by blocking the p38, JNK, PKC, and PI3K/AKT signaling pathways while it reduces the levels of the NF- $k$ B protein, resulting in the repression of MMP-2 and - 9 [74]. In addition, GA exerts a synergistic effect with doxorubicin in suppressing the growth of DU145 cells [73].

It is noteworthy that oral feeding with drinking water supplemented with $0.3 \%$ and $1 \%(\mathrm{w} / \mathrm{v})$ GA until 24 weeks of age inhibits PCa growth and progression to advanced-stage adenocarcinoma in TRAMP mice by decreasing the expression levels of Cdk2, Cdk4, Cdk6, cyclin B1, and E proteins [75]. In DU145 and 22Rv1 PC xenografts in nude mice being fed water with $0.3 \%, 1 \%(\mathrm{w} / \mathrm{v})$ of GA for 5 days/week for six weeks, GA was shown to suppress tumor cell proliferation, reduce the microvessel density of tumor xenografts, and induce apoptosis [76].

\section{Gambogic Acid}

$\nabla$

Gambogic acid is a xanthone isolated from Carcinia hanburyi (Clusiaceae) [77] that suppresses the viability of PC-3 cells at doses of $1-5 \mu \mathrm{mol} / \mathrm{L}$, and downregulates TNF- $\alpha$-induced invasion of PC-3 cells at doses of $0.125-0.5 \mu \mathrm{mol} / \mathrm{L}$ via inactivation of the PI3K/Akt and NF- $k$ B signaling pathways [78]. Gambogic acid, when injected in a xenograft prostate tumor model at $3 \mathrm{mg} / \mathrm{kg}$, was shown to suppress tumor growth and angiogenesis by inhibiting the activation of vascular endothelial growth factor receptor 2 (VEGF-2R) and its downstream protein kinases, such as c-Src and AKT [79].

\section{Genistein \\ $\nabla$}

Genistein (4',5,7-trihydroxyisoflavone) is a flavanone isolated from Glycine max (Fabaceae) [80]. Genistein acts as a tyrosine protein kinase inhibitor, thus causing a dose-dependent growth inhibition of DU145, PC-3, and LNCaP PCa cell lines via the suppression of protein phosphorylation [81]. Another study conducted in LNCaP and PC-3 cells concluded that genistein-mediated growth inhibition is caused by the downregulation of survivin, DNA topoisomerase II, cell division cycle 6 (CDC6), and mitogenactivated protein kinase 6 , and the augmented regulation of glutathione peroxidase. In PC-3 cells, suppression of cell growth is also attributed to the downregulation of the IGF-1/IGF-1R signaling pathway [82,83].

Recent studies have shown that genistein exerts its apoptotic and antiproliferative effects by regulating microRNAs. Thus, genistein is found to cause apoptosis through the downregulation of miR1260b and its target genes sRRP1 and Smad4 [84]. Furthermore, 
studies in PC-3 and DU145 cells show that genistein inhibits cell growth by modulating miR-34a and HOTAIR expression [85].

Apoptosis is also attributed to various mechanisms such as inhibition of proteasomal chymotrypsin-like activity, inactivation of $\mathrm{NF}-k \mathrm{~B}$, and inhibition of Akt [86]. Genistein in high doses has inhibitory effects due to modulating the expression of the AR function, but its growth inhibitory effect is independent of PSA expression [87]. However, genistein at physiological concentrations $(0.5-5 \mu \mathrm{M})$ activates mutant types of AR present in advanced PC [88]. Moreover, numerous genes involved in cell adhesion and migration (MMP-9, protease M, UPAR, VEGF) are downregulated in PC-3 cells after genistein treatment [89]. A recent study showed that genistein also targets cancer stem cells (CSC) and can contribute to an anti-CSC effect, which is important for inhibiting PC relapse and metastasis [90]. Epigenetics effects of genistein administrated at $40 \mu \mathrm{M}$ are also found in DU-145 and PC-3 cells, as it reverses DNA hypermethylation of tumor suppression genes leading to their activation and subsequent inhibition of cancer progression [91].

In vivo studies reveal a chemopreventive activity of genistein. Lobund-Wistar (L-W) rats that are susceptible to spontaneous and induced metastasizing adenocarcinomas in the prostate-seminal vesicle complex were found to exert a reduced incidence of induced prostate-related cancer after genistein feeding [92]. TRAMP mice fed with a phytoestrogen-rich diet containing 100 , 250 , or $500 \mathrm{mg}$ of genistein per $\mathrm{kg}$ showed a low percentage of PD (poorly differentiating) developed cancer [93].

Oral administration of genistein in PCa patients does not affect PSA levels, yet a more recent study showed that $30 \mathrm{mg}$ of synthetic genistein, given daily for three to six weeks, reduces serum PSA levels [94]. In addition, combinational treatment of metastatic-castration-resistant PCa with Cabazitaxel and genistein was found to have an enhanced apoptotic effect [95]. Clinical use of genistein against cancer is limited by its extremely low aqueous solubility, poor bioavailability, and pharmacokinetics. Based on structural analogy with steroidal compounds, liposomal vehicle compositions are designed and optimized for maximum incorporation of genistein's flavonoid structure. The pharmaceutical design of genistein-loaded liposomes seems to improve cellular delivery and specific proapoptotic effectiveness of the incorporated drug against various cancers [96]. Finally, a meta-analysis of studies that investigated soy food consumption and risk of PCa was reported. The results of this meta-analysis suggested that high consumption of non-fermented soy foods (e.g., tofu and soybean milk) might significantly decrease the risk of PC [97].

\section{Ginsenosides}

$\nabla$

Ginsenosides are compounds isolated exclusively from the plants of the genus Panax (Araliaceae). Ginsenoside Rg3 is one of the bioactive components found in ginseng root extract [98]. Rg3 has been found to arrest LNCaP cells at the G1 phase and subsequently induce a caspase3-mediated apoptosis mechanism by activating the expression of cyclin-kinase inhibitors, p21 and p27. $\mathrm{Rg} 3$ with an $\mathrm{IC}_{50}$ of $8.4 \mu \mathrm{M}$ was also shown to modulate the expression of MAP kinases, inducing cell detachment of LNCaP and PC-3 cells [99]. Further studies suggest that Rg3 interferes with the p38 MAPK pathway, causing a downregulation of AQP1 expression (water channel protein, involved in cell migration), which leads to the inhibition of cell migration and metastasis of PC-3M cells [100]. Combinational treatment of Rg3 with various chemotherapeutics (docetaxel, cisplatin, and doxorubicin) exhibits a more effective inhibition of PC cell growth in LNCaP, DU145, and PC-3 cells through the suppressed activation of NF- $k B$ [101]. $\mathrm{Rh} 2$ ginsenoside ( $\beta$-D-glucopyranoside) is a glycoside isolated from the root of Panax ginseng [102], which is also found to have antiproliferative effects and cause cell detachment, with an $\mathrm{IC}_{50}$ of $5.5 \mu \mathrm{M}$ in LNCaP and PC-3 cells, through modulations in MAP kinase expression [99]. Rh2 $(0.5-40 \mu \mathrm{M})$ and paclitaxel act synergistically and cause a significant decrease of LNCaP cell proliferation and LNCaP tumor growth [103]. Oral administration of Rh2 at a dose of $120 \mathrm{mg} / \mathrm{kg}$ in a PC-3 human xenograft model in nude mice was found to decrease tumor cell proliferation, significantly delay the tumor growth, and eventually increase the rate of apoptosis [104].

Hydroxyprotopanaxadiol (25-OH-PPD) and 20(S)-25-methoxyldammarane-3 $\beta, 12 \beta, 20$-triol (25-OCH3-PPD) were isolated from Panax ginseng as well [105]. Both were found to decrease the expression levels of proteins associated with cell proliferation (MDM2, E2F1, cyclin D1, and Cdk 2 and Cdk 4), thus causing cell cycle arrest in the G1 phase and in LNCaP and PC-3 cells. Furthermore, both compounds engender the apoptosis of $\mathrm{LNCaP}$ and PC3 cells through the activation of proapoptotic proteins (p21, p27, Bax, cleaved PARP, cleaved caspases). Finally, 25-OH-PPD inhibits tumor growth in PC-3 xenograft tumors in a dose-dependent manner, while 25-OCH3-PPD represses tumor growth in PC-3 and LNCaP xenograft tumors [106].

\section{Glycyrrhiza Compounds \\ $\nabla$}

The hexane/ethanol extract of Glycyrrhiza uralensis (Fabaceae) (HEGU), comprising the two active compounds isoangustone $\mathrm{A}$ and licoricidin, has been shown to exert anticarcinogenic effects [107].

HEGU and its active flavonoid compound isoangustone A (5,7,3',4'-tetrahydroxy-6,5'-diprenylisoflavone) were found to induce apoptosis of androgen-insensitive DU145 cells by augmenting the levels of cleaved caspase-9, caspase-7, caspase-3, and poly (ADP-ribose) polymerase (PARP) in combination with mitochondrial membrane depolarization and cytochrome $\mathrm{C}$ release to the cytosol [107]. Additionally, HEGU and its active component, isoangustone $\mathrm{A}$, diminish DNA synthesis in a dose-dependent manner, reduce the levels of CDK2, CDK4, cyclin A, and cyclin D1 proteins and decrease the CDK2 activity causing G1 phase arrest in DU145 cells [108]. HEGU also contains licoricidin, which has been shown to act as a potent antimetastatic agent. Licoricidin inhibits the metastatic and invasive capacity of malignant PCa cells by suppressing the expression of adhesion molecules and restricting the secretion and activation of the matrix metalloproteinases (MMP-2, MMP-9), TIMP-1, urokinase-type plasminogen activator, and VEGF [109].

Licochalcone (LA) (3-dimethylallyl-4,4'-dihydroxy-6-methoxychalcone) is an estrogenic flavonoid isolated from licorice root (Glycyrrhiza glabra) [110]. LA is found to cause G2/M cell cycle arrest of PC-3 prostate cells, accompanied with the suppression of cyclin B1 and cdc2 [111]. LA can also induce caspase-dependent and autophagy-related cell death in LNCaP cells [112].

Glycyrrhetinic acid (18 $\beta$-glycyrrhetinic acid) is an active triterpenoid metabolite abundantly present in licorice roots, which inhibits proliferation and growth of DU-145 cells $(10-500 \mu \mathrm{M})$ by the induction of apoptosis. It also reduces HUVEC tube formation and prevents the invasion of DU-145 PC cells on matrigel-coated 
wells via the downregulation of NF- $k$ B (p65), VEGF, and MMP-9 expression [113]. In LNCaP androgen-dependent PC cells, glycyrrhetinic acid was shown to reduce the proliferation rate as well as the production of prostate-specific antigen [114].

\section{Gossypol}

$\sqrt{10}$

Gossypol [2,2-bis-(formyl-1,6,7-trihydroxy-5-isopropyl-3-methylnaphthalene] is a polyphenolic aldehyde present in cottonseed (Gossypium hirsutum, Malvaceae) [115], which has been shown to exert antiproliferative and cytotoxic effects in PC cell lines and implanted MAT-LyLu cells in Copenhagen rats. In MAT-LyLu cells, gossypol modulates TGF $\beta 1$ and Akt signaling, altering the expression of regulatory proteins such as cyclin D1, Cdk4, and phospho-Rb and finally causing G0/G1 cell cycle arrest when delivered at $0.5-4.0 \mu \mathrm{M}$ for 24,48 , and $72 \mathrm{~h}$ [116]. Gossypol has also been found to induce G0/G1 cell cycle arrest in PC-3 cells and prostatic cells from human benign prostatic hyperplasia (BPH) patients as it evokes alterations in TGF-beta 1 expression levels. In addition, gossypol at doses of $5-20 \mu \mathrm{M}$ downregulates $\mathrm{Bcl}-\mathrm{xL}$ resulting in the inhibition of the heterodimerization of $\mathrm{Bcl}-\mathrm{xL} /$ Bcl-2 with proapoptosis molecules, which is followed by caspase-dependent and -independent apoptotic processes [117]. Recently, gossypol was shown to induce autophagy in androgenindependent PCa cells that have high levels of Bcl-2 and are resistant to apoptosis, both in vitro and in vivo (PC xenografts), by interrupting the interactions between Beclin1 and Bcl-2/Bcl-xL at the endoplasmic reticulum, thus releasing the BH3-only pro-autophagic protein Beclin1, which in turn triggers the autophagic cascade [118].

Gossypol also inhibits metastatic behaviors (adhesion, migration, and invasion) and angiogenesis. In PC-3 cells, GP suppresses AP-1 and NF- $k$ B activity, resulting in the inhibited secretion of the urokinase plasminogen activator and VEGF in combination with the downregulation of chemokine receptor 4 [119]. In human prostate tumor PC-3 xenografts in mice, gossypol at a dosage of $15 \mathrm{mg} / \mathrm{kg} /$ day prompts the suppression of angiogenesis in the solid tumors as it blocks the activation of VEGF receptor 2 kinase causing the subsequent suppression of phosphorylation of focal adhesion kinase, extracellular signal-related kinase, AKT kinase, and key intracellular proangiogenic kinases such as Src family kinase [120].

Combinational treatment of docetaxel and gossypol was found to be cytotoxic and apoptotic in PC-3 cells in a dose- and time-dependent manner [121]. Gossypol $(0.5-10 \mu \mathrm{M})$ and sorafenib (2$20 \mu \mathrm{M}$ ) were found to induce cell death via apoptotic pathways in DU-145 cells and via autophagic pathways in PC-3 cells, respectively [122]. Finally, administration of AT-101 (gossypol), at $20 \mathrm{mg} /$ day for 21 days, was found to decline PSA levels in some men with chemotherapy-naïve, castrate-resistant PCa [123].

\section{Luteolin}

$\nabla$

Luteolin ( $3^{\prime}, 4^{\prime}, 5,7$-tetrahydroxyflavone) is a flavone isolated from Terminalia chebula (Combretaceae) [124]. Luteolin induces apoptosis in various cancer cell lines (bladder, blood, bone, breast, colon, liver, lung) [5]. Induction of apoptosis in prostate DU145 cells is attributed to the up-regulation of death receptor 5 when administered at concentrations of $5-40 \mu \mathrm{M}$ for $24 \mathrm{~h}$ [125]. It also suppresses cell growth and proliferation of DU145, PC-3 cells, and
PC-3 in vivo models by inhibiting insulin like growth factor 1 (IGF-1) and the subsequent activation of IGF-1R, AKT, EGFR, and MAPK/ERK signaling [126]. In PC-3 cells, luteolin at doses of 1$100 \mu \mathrm{M}$ acts as a ligand for the nuclear type II [(3)H] estradiol binding site resulting in epigenetic changes in various genes (CCNA2 CCNE2, CDC25A, etc.) involved in the cell cycle [127]. Luteolin $(10-40 \mu \mathrm{M})$ also suppresses angiogenesis and invasion through the downregulation of VEGF-2R in PC-3 cells in vitro and in vivo and through the downregulation of AR and PSA expression in LNCaP cells, respectively [128].

\section{Lycopene \\ $\nabla$}

Lycopene ( $\psi, \psi$-carotene) is a carotenoid mostly isolated from Solanum lycopersicum (tomato; Solanaceae) [129]. Extensive research has been conducted both in vitro and in clinical trials in order to identify the mechanisms of lycopene's cytotoxic and chemopreventive effects against PCa. More specifically, lycopene is found to induce cell cycle arrest and apoptosis in PC-3, LNCaP, DU145 cells, and DU145 xenografts. In LNCaP cells, lycopene induces mitochondrial-related apoptosis when delivered in physiologic concentrations $(0.3-3.0 \mu \mathrm{M})$, whereas in high concentrations ( $>5 \mu \mathrm{M})$, it leads to DNA damage [130]. A lycopene-mediated reduction in cholesterol synthesis was also shown through the activation of the PPAR $\gamma$-LXR $\alpha$-ABCA1 pathway both in LNCaP and DU145 cells [131]. In PC-3 cells and xenograft models, high concentrations of lycopene ( $16 \mathrm{mg} / \mathrm{kg}$ twice a week for seven weeks) induced apoptosis through alterations in IGF-I, IGF-IR, and IGFBP3 expression levels [132]. Both in LNCaP and PC-3 cells, G0/G1 cell cycle arrest is caused by lycopene via its interference with phosphatidylinositol 3-kinase signaling, which leads to a decrease in Cdk4, cyclins D1 and E, and Rb phosphorylation. Cell cycle arrest and apoptosis are also attributed to a reduced activation of NF- $k B$ in combination with an increased expression of p21, p27, and p53, shifting the Bax:Bcl-2 ratio. Migration and invasion of LNCaP and PC-3 cells are also suppressed by lycopene via a reduction in the expression levels of integrins $[133,134]$.

Moroever, lycopene acts also as a chemopreventive agent, delaying or preventing the establishment of PCa. In LNCaP cells, lycopene exerts its chemopreventive effect through an increase in detoxification proteins and subsequent prevention of DNA damage, and suppresses ROS generation and oxidative stress as well [135]. Chemopreventive activity of lycopene was also found in TRAMP mice fed $28 \mathrm{mg}$ lycopene per $\mathrm{kg}$ for 20 weeks [136].

In clinical trials, lycopene was found to be more of a chemopreventive agent than a cytostatic agent of established tumors. Lycopene given to patients at a dose of $4 \mathrm{mg}$ twice a day for one year was shown to delay or prevent high-grade prostate intraepithelial neoplasia from developing into PC [137], whereas whole tomato lycopene administration in men with established PCa at a dose of $10 \mathrm{mg}$ per day for one year resulted in a reduced PSA velocity [138]. Finally, recent epidemiologic studies have suggested a potential benefit of lycopene against the risk of PCa. Five studies support a 30 to $40 \%$ reduction in risk associated with high tomato or lycopene consumption, three are consistent with a $30 \%$ reduction in risk, but the results were not statistically significant, and seven were not supportive of an association [139]. 


\section{Compounds Derived from Magnolia sp. \\ $\nabla$}

Honokiol (2-(4-hydroxy-3-prop-2-enyl-phenyl)-4-prop-2-enylphenol), a lignan isolated from Magnolia officinalis (Magnoliaceae) [140], has been found to decrease the viability of PC-3 and LNCaP human PCa cells in a dose- and time-dependent manner through G0-G1 phase cell cycle arrest. Honokiol also triggers apoptotic DNA fragmentation in a dose- $(20-60 \mu \mathrm{M})$ and time-dependent (24-72 h) manner both in androgen-dependent and -independent prostate cell lines (PC-3, LNCaP, and C4-2), which is correlated with the induction of Bax, Bak, and Bad in addition to a decrease in Bcl-xL and Mcl-1 protein levels [141,142]. Likewise, honokiol treatment exhibits growth inhibitory, apoptotic, and antiangiogenic effects on PC xenografts fed with 1-3 mg honokiol thrice a week [141].

Magnolol (4-allyl-2-(5-allyl-2-hydroxy-phenyl)phenol) is a hydroxylated biphenyl (lignan) isolated from the root and stem bark of Magnolia officinalis [140]. Magnolol was shown to induce apoptotic cell death in a dose-dependent $(10-60 \mu \mathrm{M})$ manner in PC-3 cancer cells through epidermal growth factor receptor (EGFR)-mediated signaling transduction pathways and also inhibits the adhesion, invasion, and migration of PC-3 human prostate [143].

Obovatol (5-prop-2-enyl-3-(4-prop-2-enylphenoxy)benzene1,2-diol), a biphenyl ether lignan isolated from Magnolia obovata [144], engages LNCaP and PC-3 cells to apoptotic cell death through the inhibition of NF- $k$ B activity and also enhances the cell growth inhibition of chemotherapeutics (docetaxel, paclitaxel, cisplatin, and doxorubicin) [145].

\section{Oridonin}

$\nabla$

Oridonin (7a,20-epoxy-1a,6b,7,14-tetrahydroxy-Kaur-16-en-15one) is an isoprenoid (kaur-type diterpenoid) isolated from Rabdosia rubescens (Labiatae) [146]. Oridonin has been found to elicit G0/G1 cell cycle arrest and apoptosis of LNCaP cells through the upregulation of p53 and Bax and the downregulation of Bcl-2 expression in a dose-dependent manner [147]. Oridonin has also been shown to trigger G2/M cell cycle arrest, autophagy, and apoptosis in LNCaP and PC-3 cells by upregulating the expression of p21 in a time- $(12-72 \mathrm{~h})$ and dose-dependent $(10,25-100 \mu \mathrm{M})$ manner [148].

\section{Phenethyl-Isothiocyanat}

$\nabla$

Phenethyl-isothiocyanat [(2-isothiocyanato-ethyl)benzene] (PEITC) is one of the most extensively studied isothiocyanates (ITCs) that is found in cruciferous vegetables such as broccoli (Brassica oleracea) and watercress (Nasturtium officinale) of the Brassicaceae family, brussels sprouts, cabbage, Japanese radish, and cauliflower [149].

In DU145 cells, PEITC (1-20 $\mu \mathrm{M})$ suppresses cell proliferation and causes cell cycle arrest in the G2/M phase and apoptosis in a dose-dependent manner. The mechanism of PEITC action suggests that it increases p53 expression while it reduces CDC25C, inhibits the JAK-STAT3 signal cascade, and modulates the activation of the caspases pathway [150].

PEITC $(5-20 \mu \mathrm{M})$ has also been described to induce G2-M cell phase arrest and inhibit the expression of $\alpha$ - and $\beta$-tubulin proteins in LNCaP, DU145, PC-3, and C4-2B cells through reactive oxygen species generation and protein degradation [151]. Other studies show that PEITC represses the androgen receptor's expression through the inhibition of Sp1 transcription, thus mediating growth arrest both in androgen-dependent and -independent PC cells [152].

In LNCaP and PC-3 cells, PEITC ( 2.5 and $5 \mu \mathrm{M})$ triggers apoptotic mechanisms via the activation of Bax and ROS production, whereas it downregulates survivin and X-linked inhibitors of apoptosis [153]. It is noteworthy that PEITC induces both apoptotic and autophagic cell death in PC-3 and LNCaP cells regulated by Atg5 protein [154].

Furthermore, PEITC ( 2.5 and $5 \mu \mathrm{M})$ was shown to restrain migration of PC-3 and LNCaP cells. The suggested mechanisms propose that PEITC treatment leads to inactivation of Akt with a subsequent suppression of VEGF and interference with the Notch pathway [155].

PEITC was found to cease angiogenesis both in human umbilical vein endothelial cells (HUVEC) and in ex vivo experiments (chicken egg chorioallantoic membrane assay) [156]. In xenograft models, similar results were observed. When administered orally at a dose of $12 \mu \mathrm{M}$ /day for five days per week, PEITC delays growth of PC-3 xenografts in athymic mice [157]. In an LNCaP xenograft model, PEITC regulates tumor growth by suspending the expression of the platelet/endothelial cell adhesion molecule (PECAM1CD31) and by the suppression of angiogenesis [158]. Studies in transgenic adenocarcinoma of the mouse prostate, in mice fed with $3 \mu \mathrm{mol} \mathrm{PEITC/g}$ for 19 weeks, also revealed inhibition of prostate carcinogenesis induced by the overexpression of E-cadherin and autophagy-regulated pathways [159].

Finally, the combination treatment of PEITC $(2 \mu \mathrm{M})$ with docetaxel ( $1 \mathrm{nM})$ increased the rate of apoptosis in PC-3 and DU145 cells by the suppression of $\mathrm{Bcl} 2$ and the induction of Bax and Bak proteins, while combinational treatment of PEITC with adriamycin and etoposide led to PC-3 cell death through the downregulation of protein kinase $C$ and inhibition of telomerase [160].

\section{Quercetin}

\section{$\nabla$}

Quercetin (2-(3,4-dihydroxyphenyl)-3,5,7-trihydroxy-4H-chromen-4-one) is a polyphenol (flavonol) isolated from grapes (V. vinifera, Vitaceae) [63]. Quercetin was found to reduce cell growth and cause apoptosis in various cell lines (bladder, blood, bone, breast, colon, liver, lung, mouth, esophagus) [5]. Quercetin reduces cell growth of PC-3, LNCaP, and DU145 PC cells in a dosedependent manner by interfering with the expression levels of numerous oncogenes and tumor suppressor genes. In LNCaP, quercetin causes G2/M cycle arrest due to p21 upregulation and cyclin B suppression [161]. Studies in PC-3 cells suggest that growth inhibition is caused by a decreased phosphorylation of ErbB-2, ErbB-3, c-Raf, MAPK kinase 1/2 (MEK1/2), and MAPK, Akt- 1 and is combined with a reduced metastatic rate and drug resistance. In addition, quercetin has been described as interfering with c-Jun and SP1, causing AR reduction [162].

Quercetin at doses of $5-100 \mu \mathrm{M}$ was also shown to provoke apoptosis in PCa cell lines through inhibition of fatty acid synthase and downregulation of heat shock protein 90 [163]. More studies showed that quercetin induces G2/M cycle arrest and apoptosis of PC-3 cells via a decrease in Cdc2/Cdk-1, cyclin B1, phosphorylated pRb, IGF-I, and IGF-II and an increase in p21, Bax, and caspase-3, and modulations of the Bcl-2/Bax ratio [164]. In addition, quercetin augments TRAIL-induced cytotoxicity through caspase 
activation, inhibition of surviving, and Akt phosphorylation [165]. Moreover, in vitro and in vivo studies in prostate xenograft mouse models depict quercetin's antiangiogenetic effects as it interacts with the VEGF-R2-regulated autophagic (AKT/mTOR/ P70S6K) pathway when administered at a dose of $20 \mathrm{mg} / \mathrm{kg} /$ day [166].

\section{Sanguinarine \\ $\nabla$}

Sanguinarine (13-methyl-[1,3]benzodioxolo[5,6-c]-1,3-dioxolo [4,5-i]phenanthridinium) is a benzophenanthridine alkaloid derived from Sanguinaria canadensis (Papaveraceae) (the bloodroot plant) [167]. In LNCaP and DU145, sanguinarine causes G0/G1 cell cycle arrest in a dose-dependent manner $(0.1-2 \mu \mathrm{M})$ by interfering with the expression of cyclin kinase inhibitors p21/WAF1 and p27/KIP1, cyclin E, D1, and D2 and cyclin-dependent kinases 2,4 , and 6 [168].

Sanguinarine has also been shown to confine PCa cells growth and induce apoptosis at concentrations of $0.1-8 \mu \mathrm{M}$. This has been attributed to the suppressed expression of survivin and protein degradation via the ubiquitin-proteasome system [169]. Treatment of DU145, C4-2B, and LNCaP cells with sanguinarine $(2 \mu \mathrm{M}$ and $4 \mu \mathrm{M}$, for $1-12 \mathrm{~h}$ ) revealed that it restricts PCa growth, migration, and invasion through Stat3 inactivation [170]. In DU145 cell xenografts, the administration of sanguinarine $(0.25 \mathrm{mg} / \mathrm{kg}$ and $0.5 \mathrm{mg} / \mathrm{kg})$ reduced tumor weight and volume after 31 days [169].

\section{Silibinin}

$\nabla$

Silibinin or silybin (3,5,7-trihydroxy-2-(3-(4-hydroxy-3-methoxyphenyl)-2-(hydroxymethyl)-1,4-benzodioxan-6-yl)-4-chromanone) is a flavolignan isolated from the fruits of Silybum marianum (Asteraceae) [171]. Silibinin has been described as causing G1 cell cycle arrest and decreasing both intracellular and secreted forms of PSA in LNCaP cells in a dose- $(50-200 \mu \mathrm{M})$ and time-dependent (12-48 h) manner, which has been attributed to modulations of retinoblastoma $(\mathrm{Rb})$ levels and its phosphorylation status combined with a decreased activity of cyclin-dependent kinases (CDKs) [172]. Further studies in LNCaP cells revealed that the decrease of PSA was caused by the downregulation of the androgen receptor's coactivator and the epithelium-derived Ets transcription factor (PDEF) [173]. Silibinin was not only shown to suppress global protein translation, thus inhibiting HIF-1 alpha expression and telomerase activity [174], but also, as a lipophilic compound, was found to compete in the EGF-erbB1 interaction and to interfere with the mitogenic signaling and DNA synthesis in LNCaP and DU145 cells [175].

In DU145 cells, silibinin treatment (50-200 $\mu \mathrm{M}$, for 24 and $48 \mathrm{~h}$ ) caused G1 cell cycle arrest mediated by a decrease in p21 and p27 expression [176]. Silibinin also restrains Wnt/LRp6 signaling and induces apoptosis through the inhibition of active Stat 3 while it sensitizes cells to TNF $\alpha$-induced apoptosis through constitutive NF- $\kappa$ B inactivation [177].

Silibinin at pharmacologically achievable concentrations (0.02$20 \mu \mathrm{M}$ ) causes G1 and G2/M cycle arrest in PC-3 cells by interfering with the expression levels of cyclins and CDKs [178] and the insulin-like growth factor I receptor-mediated signaling pathway [179].
Silibinin has also been found to prevent migratory and invasive potential of PC-3, PC-3MM2, C4-2B LNCaP, and DU145 cells [180]. In general, silibinin inhibits the epithelial to mesenchymal transition of PC cells through interference with the NF- $k$ B pathway and subsequent downregulation of ZEB1 and SLUG transcription factors and by downregulating vimentin and MMP2 [181]. Silibinin also exerts inhibitory effects in high bone metastatic prostate models and prevents PC cells-induced osteoclastogenesis [182].

In xenograft models, silibinin is described as having antiproliferative, proapoptotic, and antiangiogenic effects. Studies in PC-3 tumor xenografts in athymic mice revealed that silibinin effects are attributed to an increase in IGFBP-3, Cip1/p21, and Kip1/p27 levels, activation of ERK1/2, and a decrease in Bcl-2 and VEGF levels. In TRAMP mice fed $0.5 \%$ and $1 \% \mathrm{w} / \mathrm{w}$ silybin-phytosome diets for 11 weeks, silibinin blocked PCa growth and progression through IGF-IGFBP-3 axis modulation, whereas it suppressed tumor microvessel density via a decrease in VEGF, VEGFR-2, MMPs, and vimentin [183]. Finally, in patients receiving a silybin-phytosome (13 g/day) for 14-31 days, high blood concentrations were found transiently, but low levels of silibinin were detected in prostate tissue. Silibinin's lack of tissue penetration may be explained by its short half-life, the brief duration of therapy in this study, or an active process of removing silibinin from the prostate [184].

\section{Sulforaphane \\ $\nabla$}

Sulforaphane (1-isothiocyanato-4-methylsulfinylbutane) (SFN) is a natural isothiocyanate found in many cruciferous vegetables, firstly isolated from Brassica oleracea (broccoli; Brassicaceae) [185]. Many studies have shown that SFN can provoke cell cycle arrest and apoptosis in androgen-dependent and androgen-refractory PC cell lines. SFN ( IC $_{50}$ of $10 \mu \mathrm{M}$ ) causes $\mathrm{G} 2 / \mathrm{M}$ phase arrest in DU145 cells [186] and G1 cell cycle arrest in LNCaP and PC3 cells. The antiproliferative effects of SFN at doses of $10-40 \mu \mathrm{M}$ involve mechanisms such as the modulation of methyltransferases expression, which leads to an increase in cyclin D2 in LNCaP cells, and protein synthesis inhibition through decreased phosphorylation of mTOR substrates in PC-3 cells [187]. Apoptosis is induced through caspase activation in LNCaP cells, ROS generation that triggers intrinsic and extrinsic caspase cascades in PC-3 and DU145 cells [186], and inhibition of histone deacetylase 6 in BPH-1, LNCaP, and PC-3 cells $[188,189]$. SFN has also been reported to inhibit HIF- $1 \alpha$ with a subsequent decrease in VEGF expression, thus preventing prostate cell angiogenesis [190]. Cell migration of PC-3 and LNCaP cells is also restricted by SFN when delivered at $20 \mu \mathrm{M}$ for 8 and/or $24 \mathrm{~h}$ due to modulations of the Notch pathway [191].

In vivo studies have deduced that oral administration of a daily dose of $7.5 \mathrm{mmol}$ per animal for 21 days in PC-3 xenografts in nude mice causes a $>50 \%$ reduction in tumor volume due to a decrease in HDAC activity. Finally, TRAMP mice that were fed broccoli sprouts exhibited a decrease in prostate tumor growth [192].

\section{Thymoquinone}

\section{$\nabla$}

Thymoquinone (2-isopropyl-5-methylbenzo-1,4-quinone) (TQ) is a phytochemical isolated from the plant Nigella sativa (Ranunculaceae) [193]. TQ (40-100 $\mu \mathrm{M})$ has been found to reduce cell 


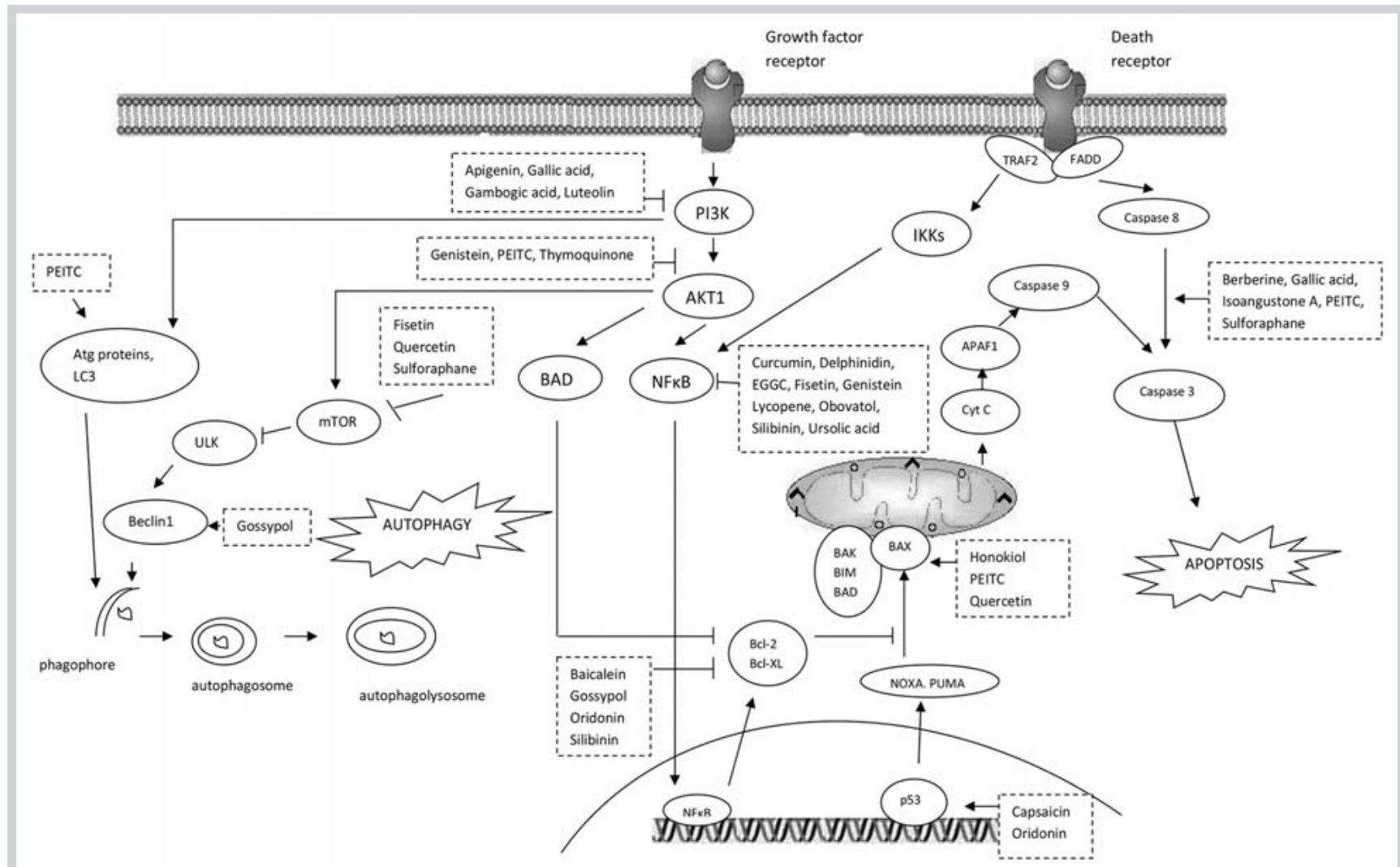

Fig. 1 Mechanism of action of bioactive natural products in prostate cancer cells. Natural compounds provoke apoptosis of PCa cells by triggering caspases (berberine, gallic acid) and mitochondrial-dependent cascades (honokiol) or by inhibiting oncogenes (baicalein), and by suppressing the NFKB signaling pathway (curcumin). Other compounds trigger autophagy via inhibition of the PI3K signaling pathway (apigenin), suppression of the mTOR complex (fisetin), or activation of the phagophore formation-related proteins (PEITC, gossypol). growth both in androgen-dependent (LNCaP, C4-B) and androgen-refractory (DU145, PC-3) PC cell lines. Cell growth reduction is attributed to a decrease in AR and E2F-1 as well as the E2F-1 regulated proteins [194]. In PC-3 and C4-B cells, TQ (IC 50 values of approximately 50 and $80 \mathrm{mM}$ ) was shown to induce apoptosis through increased ROS generation and decreased GSH levels [195]. Other studies in PC-3 cells also demonstrated that TQ inhibits cell proliferation through suppression of AKT and prevents tumor angiogenesis via the repressed activation of induced extracellular signal-regulated kinase by VEGF [196].

\section{Ursolic Acid}

$\nabla$

Ursolic acid ((3 3 )-3-hydroxyurs-12-en-28-oic acid) (UA) is a pentacyclic triterpenoid compound derived from Cornus officinalis (Cornaceae) [197].

In PC-3 cells, UA evokes apoptosis via extrinsic and intrinsic apoptotic pathways while it confines cell invasion by inhibiting Akt and downregulating matrix metalloproteinase-9 [198]. UA was also shown to induce apoptosis through JNK activation, which results in Bcl-2 phosphorylation and degradation causing the activation of caspase 9, both in androgen-dependent (LNCaP) and androgen-independent PCa cell lines (LNCaP-AI and DU145 cells) [199]. In addition, UA displays a role in the suppressed activation of NF- $k$ B and STAT3 by downregulating the expression of various NF- $k$ B and STAT3 gene products involved in proliferation, survival, and angiogenesis, and thus induces apoptosis in PCa cell lines
(LNCaP, DU145) and TRAMP mice [200]. UA was also found to restrict metastasis through the suppression of CXCR4 expression in PC both in vitro (PC-3, LNCaP, DU145 cells) and in vivo (TRAMP mice fed $1 \% \mathrm{w} / \mathrm{w}$ UA for 6 to 8 weeks) [201]. Finally, in DU145 cells, UA and its cis- and trans-3-0-p-hydroxycinnamoyl esters derived from American cranberries, such as Vaccinium macrocarpon, were shown to limit tumor cell growth at micromolar concentrations through matrix metalloproteinase (MMP-2 and MMP-9) inhibition [202].

\section{Conclusion}

In this review article, the most promising bioactive natural products and their respective mechanisms of action for the treatment of PCa are presented, as they affect the processes of cell proliferation, cell cycle control, apoptosis, autophagy, tumor angiogenesis, invasion, and metastasis ( Fig. 1, Table 1). Indeed, a variety of natural products have gained widespread use in the clinical treatment of a number of malignancies, such as carcinomas of the colon, breast, ovary, lung, and prostate. Unlike conventional chemotherapy, targeted agents have a relatively wide therapeutic window and have nonoverlapping toxicity profiles. Natural compounds that interfere with essential carcinogenic pathways, without demonstrating severe side effects, could exert a significant role as chemotherapeutic or chemopreventive agents, thus offering an alternative or complementary approach to the treatment of cancer. However, further in vivo studies should be con- 


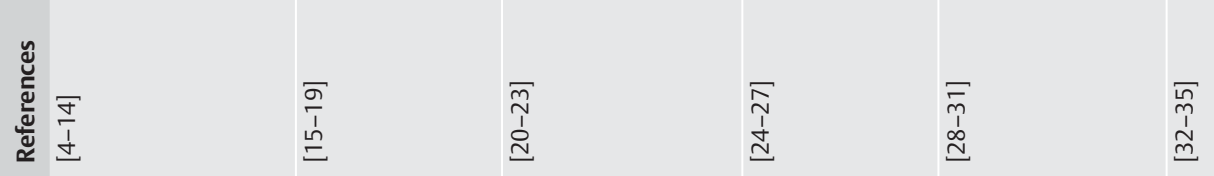
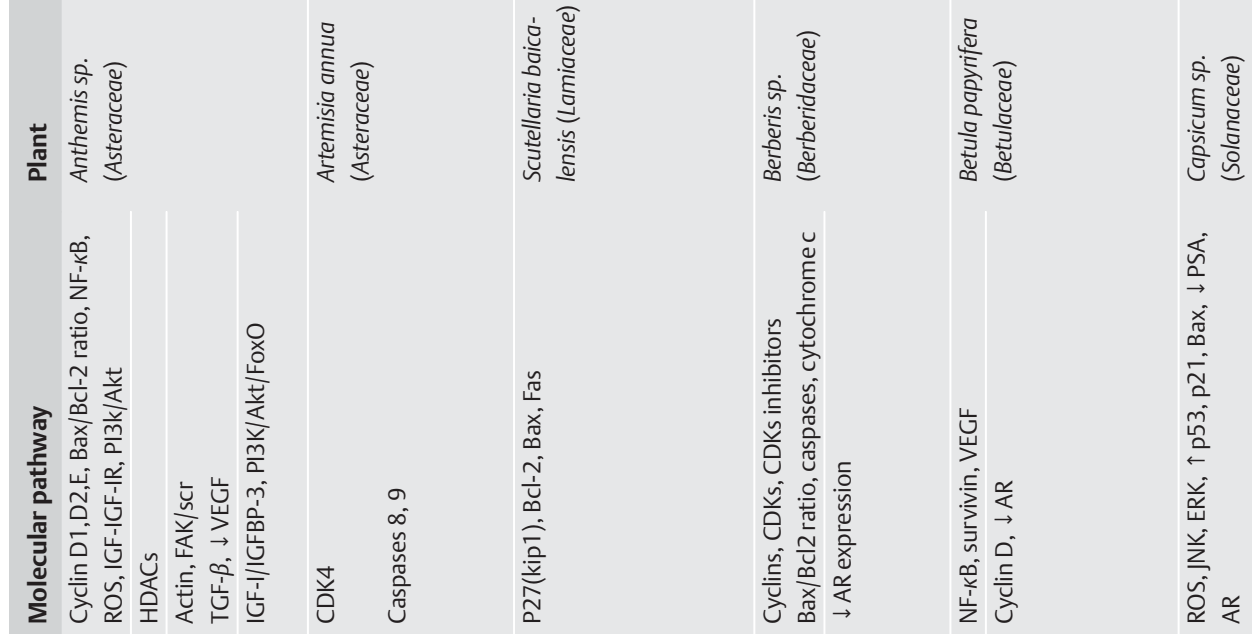

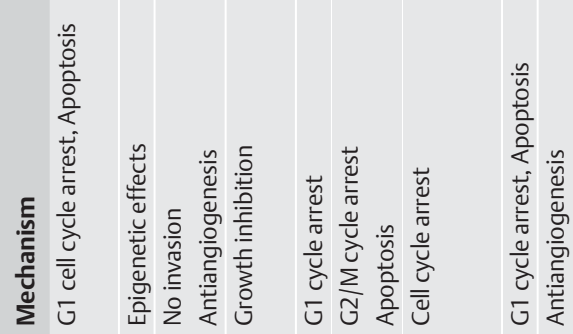

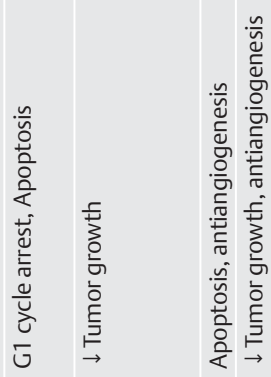

ปั
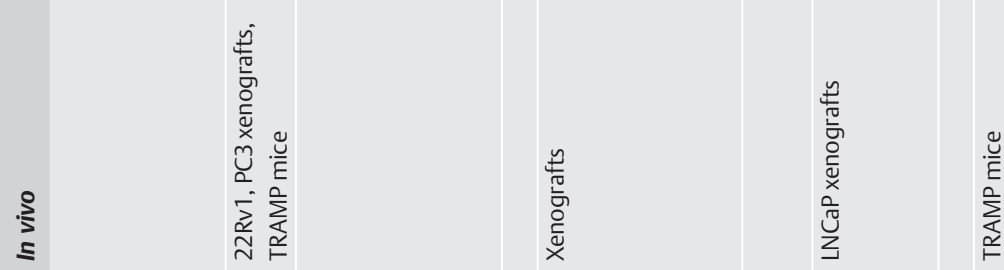

$\frac{n}{\grave{n}}$
$\frac{\hat{0}}{2}$
$\frac{0}{x}$
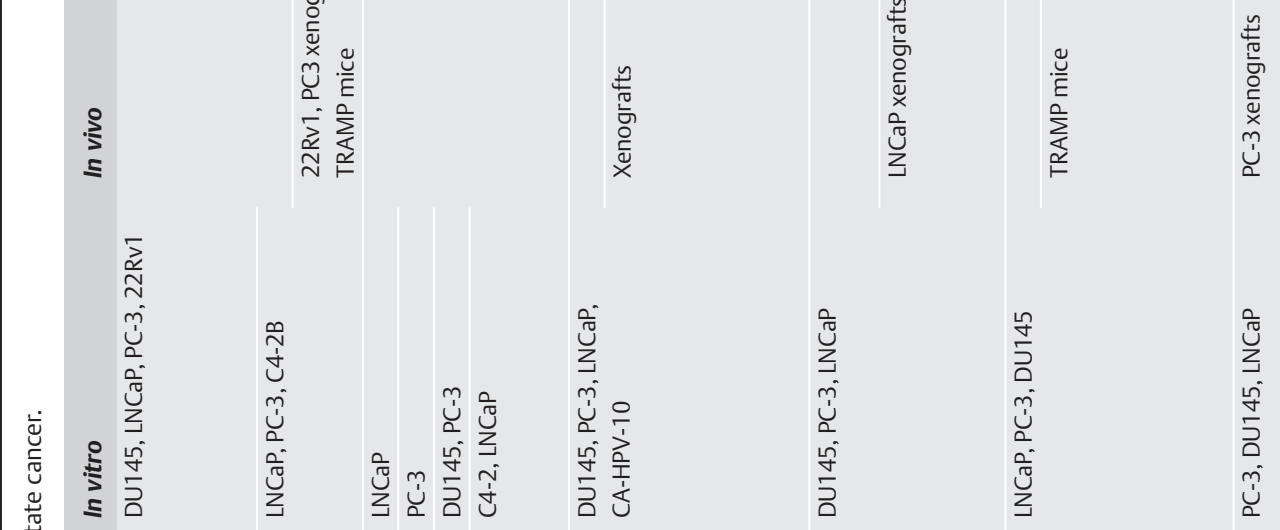

을

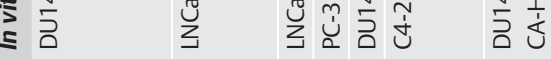

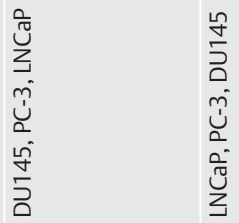

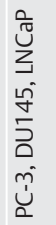

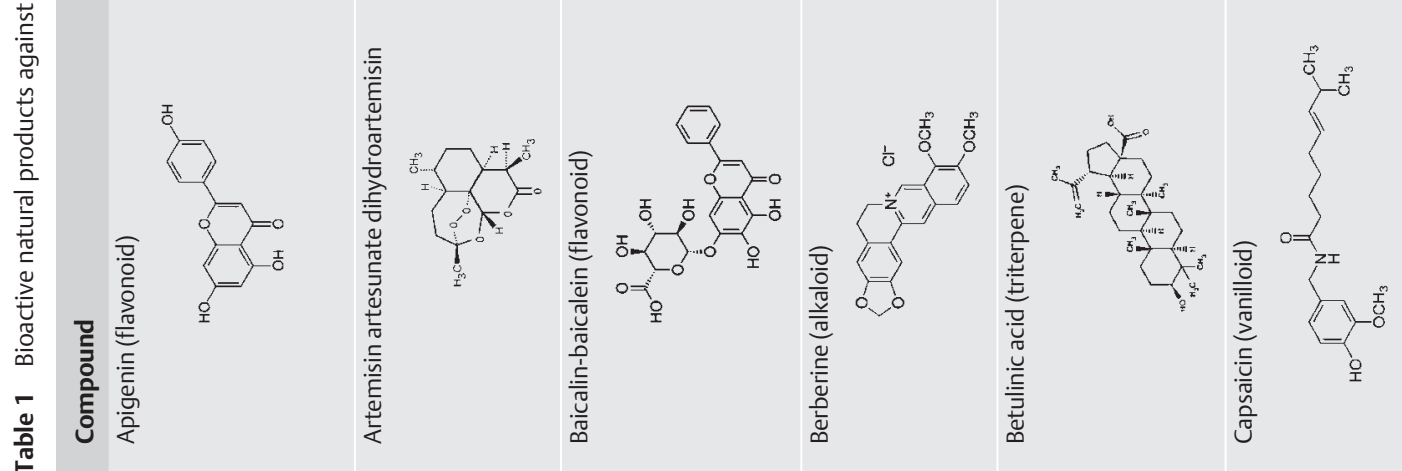




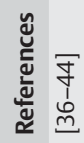

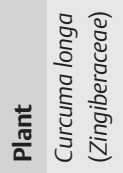

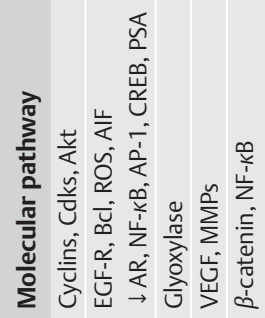

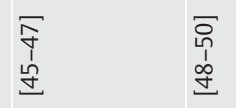

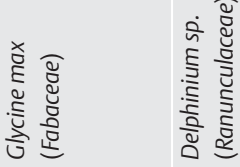

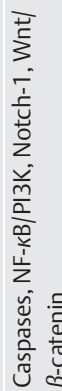

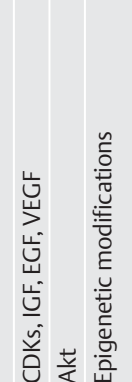

商

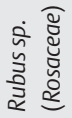

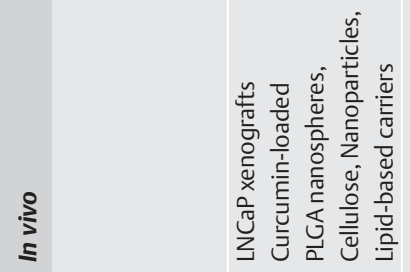

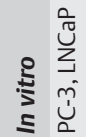

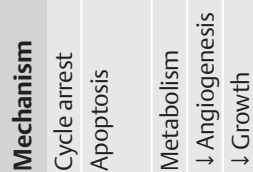

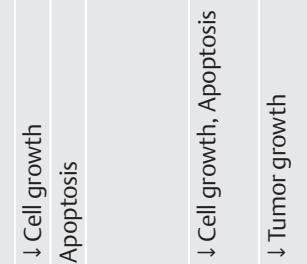

$\overline{5}$
$\vdots$
$\vdots$

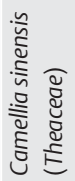

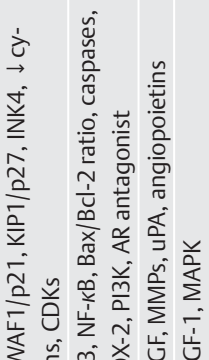

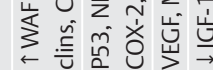

$\overline{6}$
$\stackrel{1}{0}$
$\underline{0}$
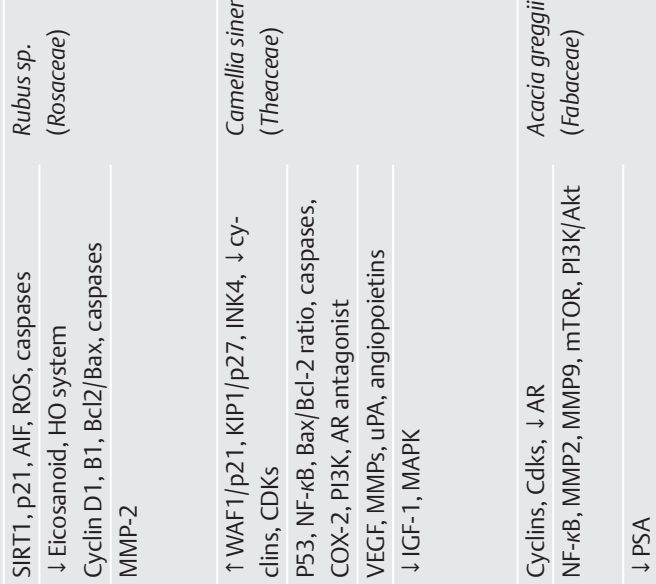

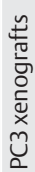
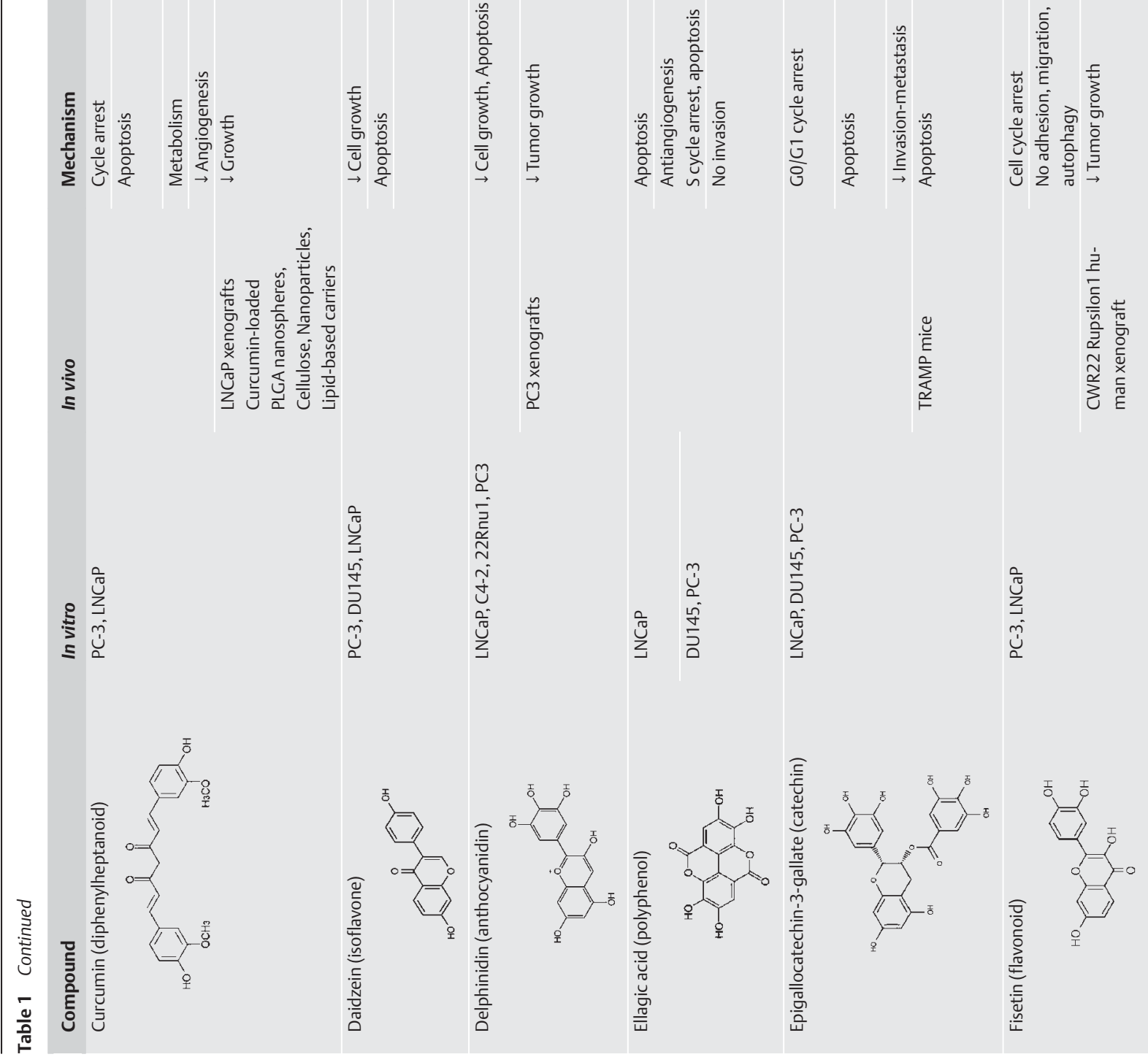


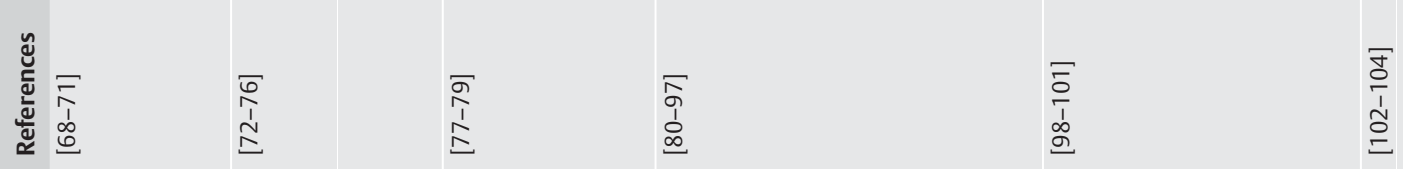

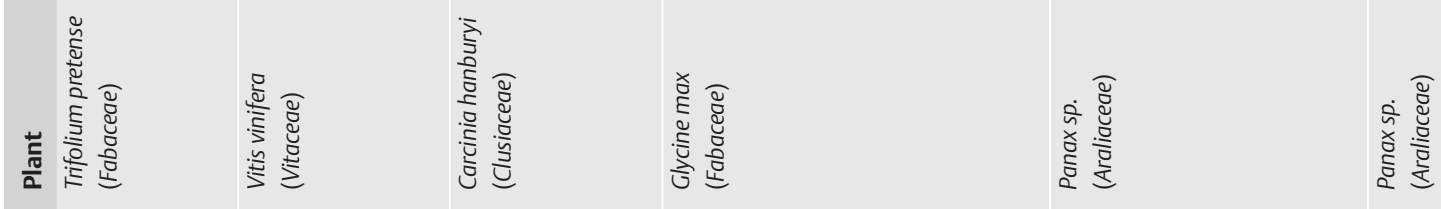

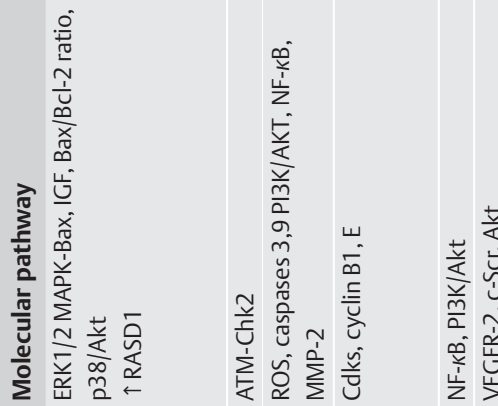

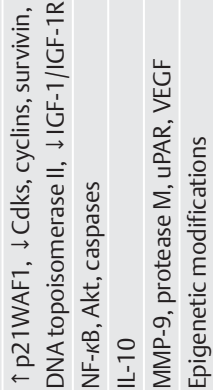

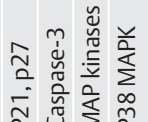

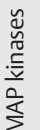
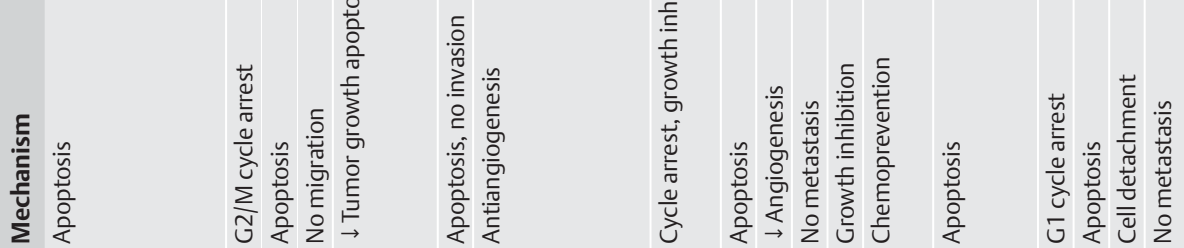

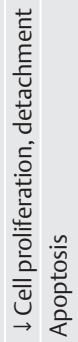
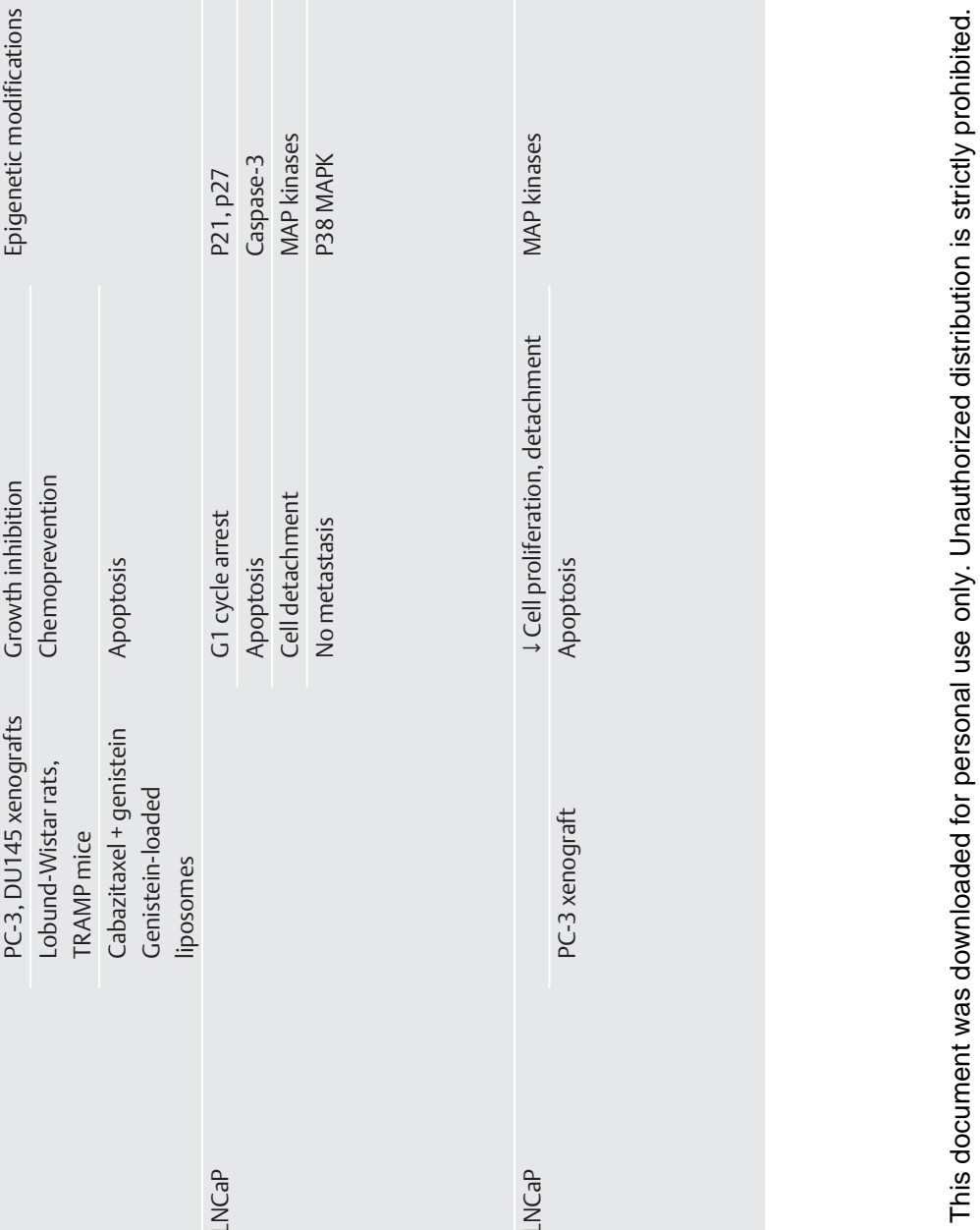

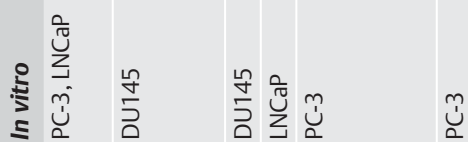

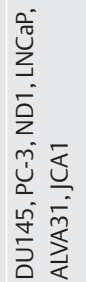

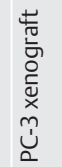
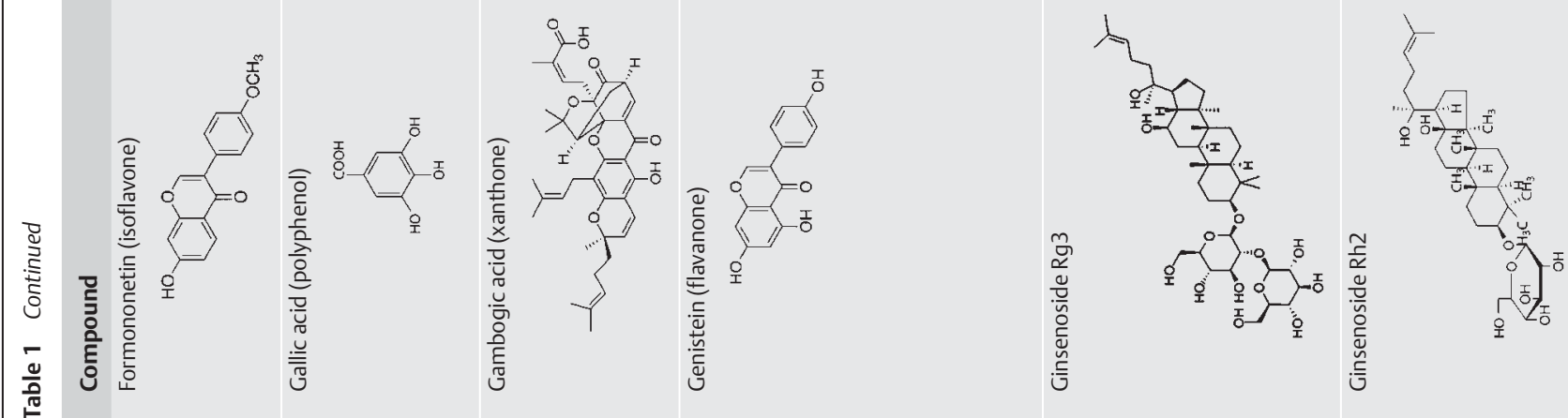


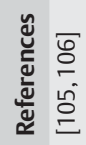

E
m̃
E

क
$\frac{1}{1}$
0
0

$\begin{array}{ll}\bar{N} & \bar{N} \\ & \frac{1}{n} \\ \vdots & \underline{n}\end{array}$

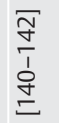

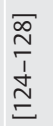

范

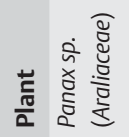

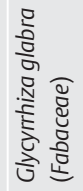

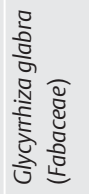

ह⿱艹

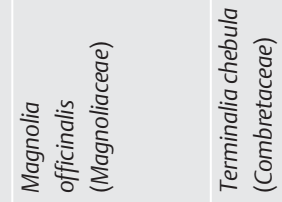

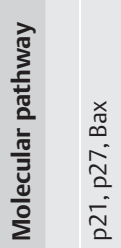

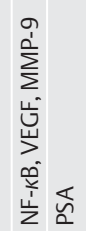

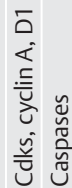

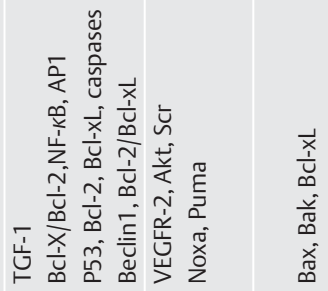

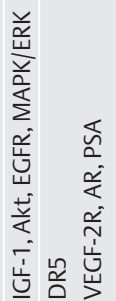

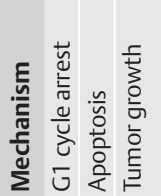

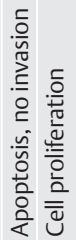
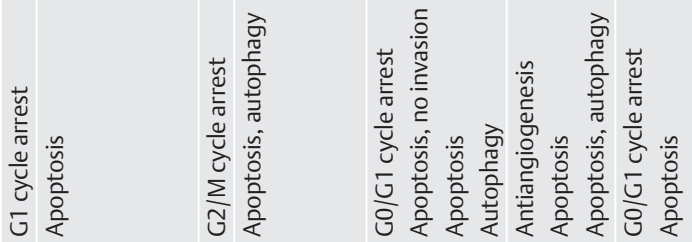

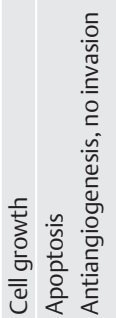

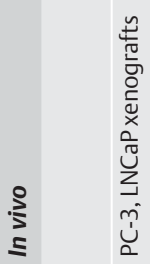

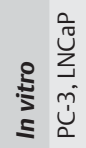

$\frac{0}{3}$
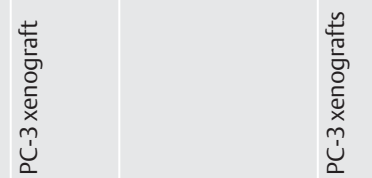

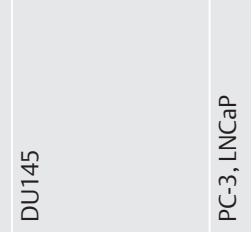

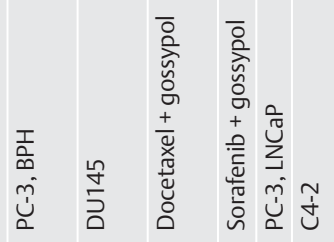

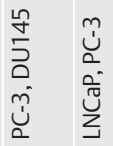
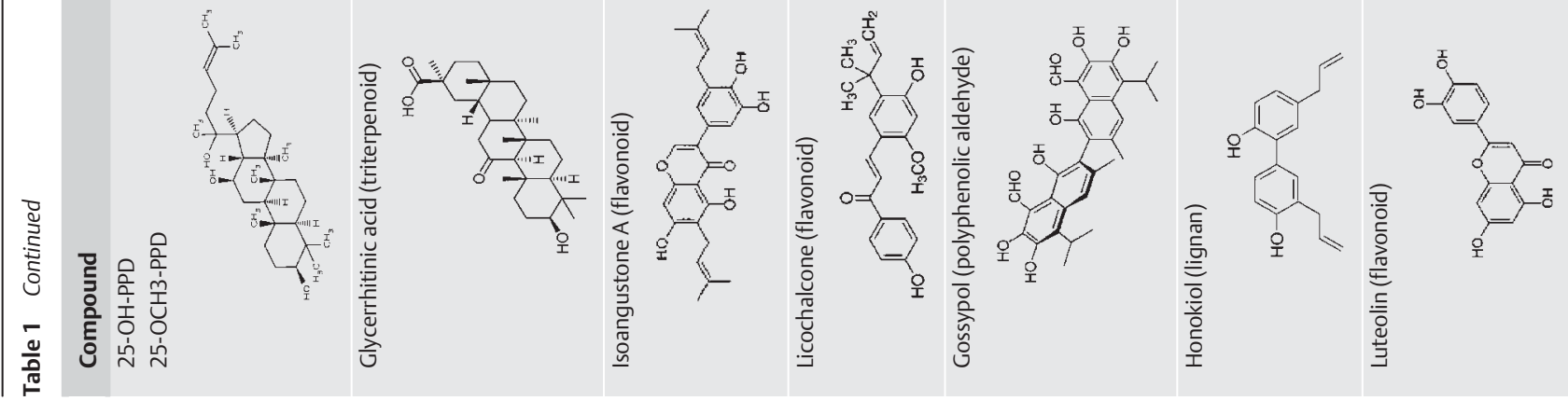


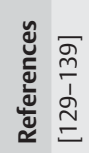

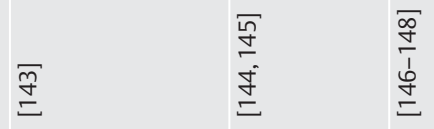

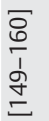

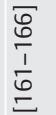

$\overline{1}$
$\frac{1}{1}$
$\frac{1}{6}$

范

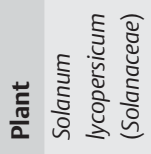
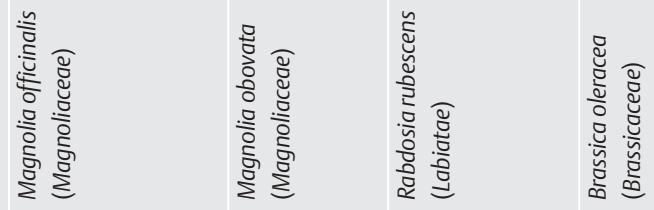

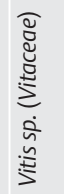

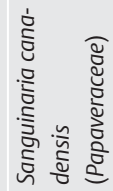

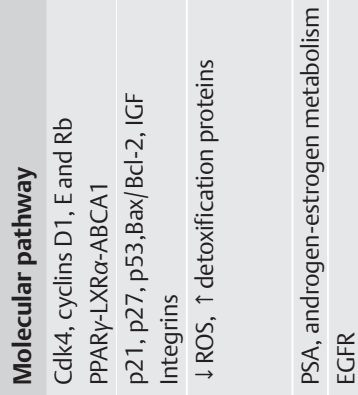

$\stackrel{\frac{m}{i}}{\frac{m}{2}}$

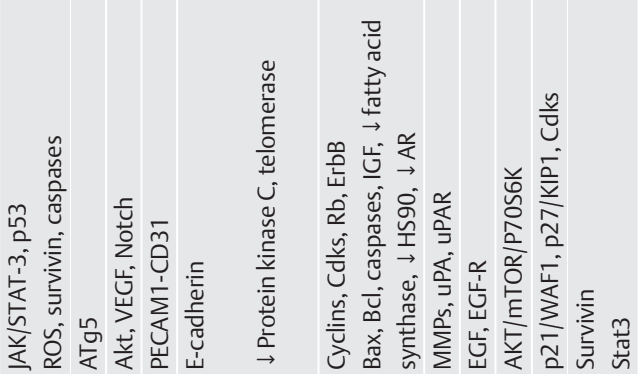

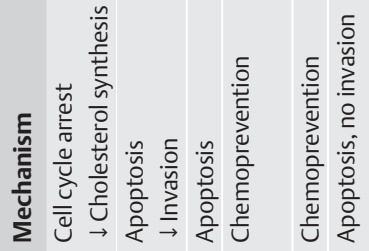

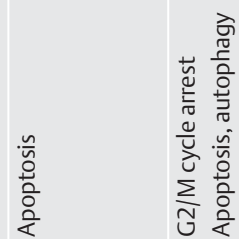
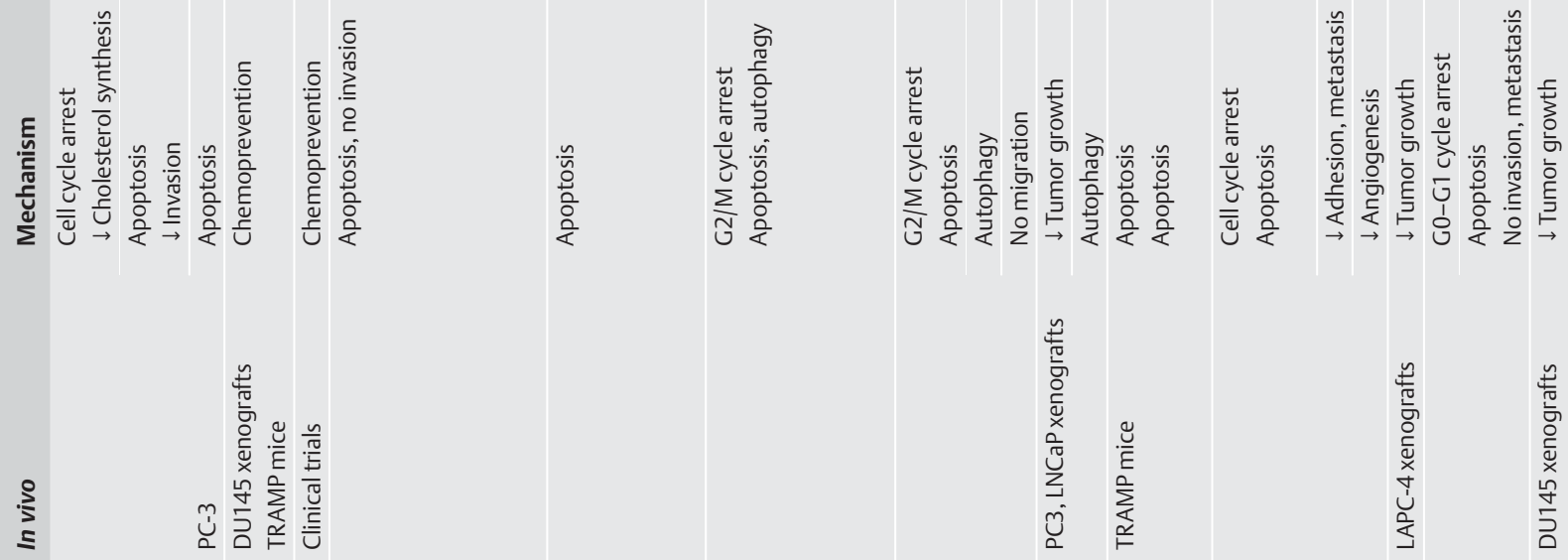

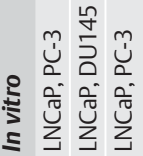

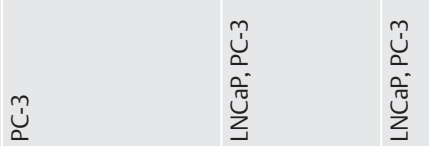

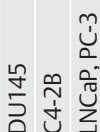
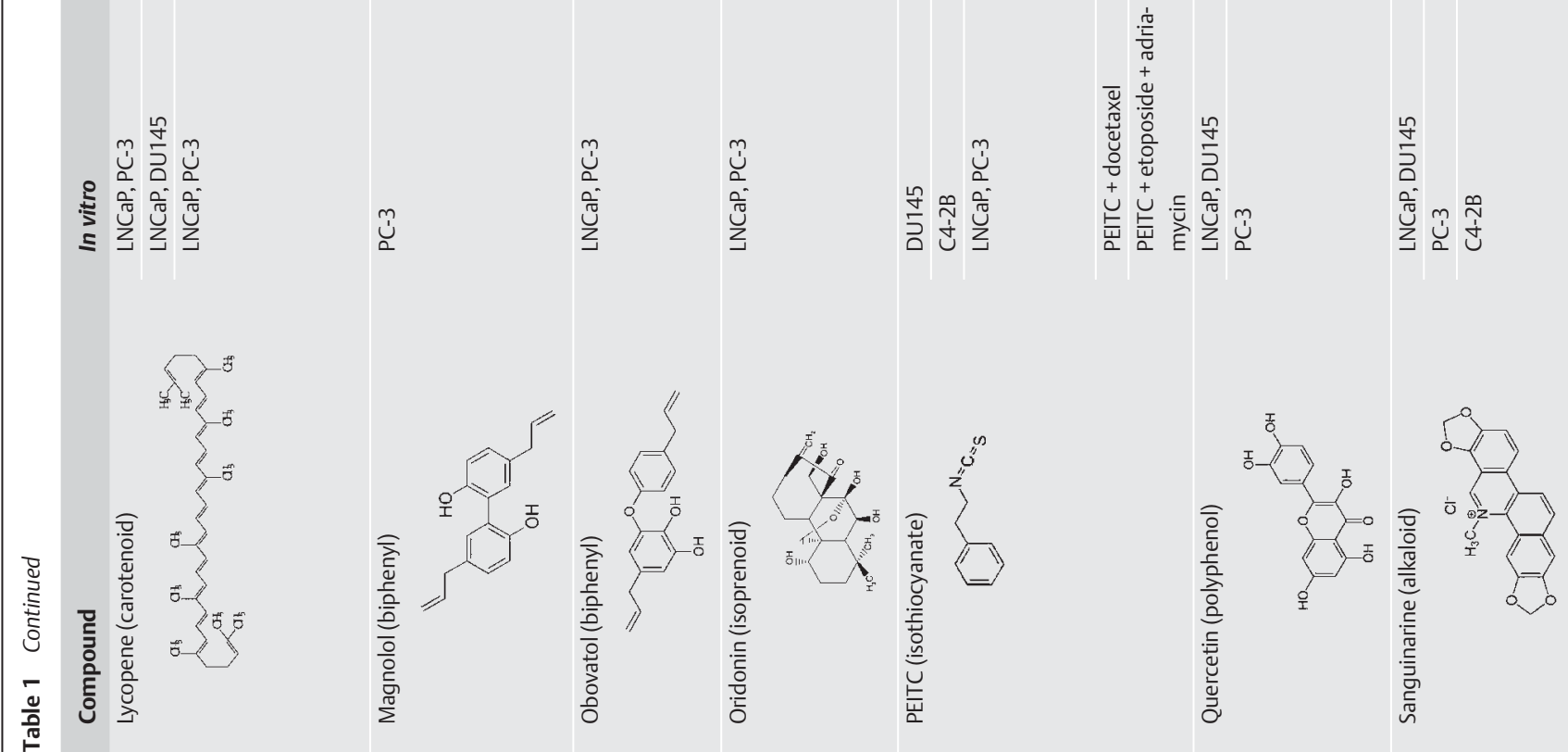


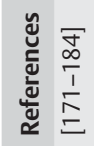

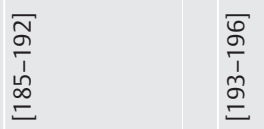

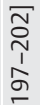

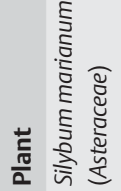

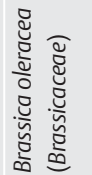

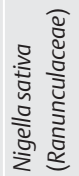

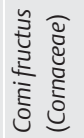

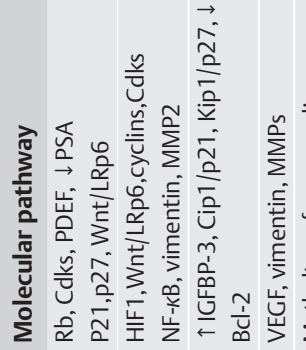

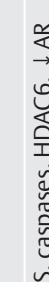

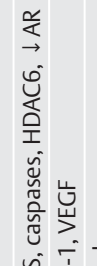

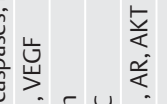

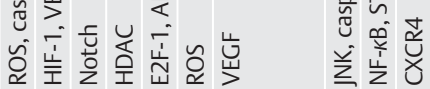
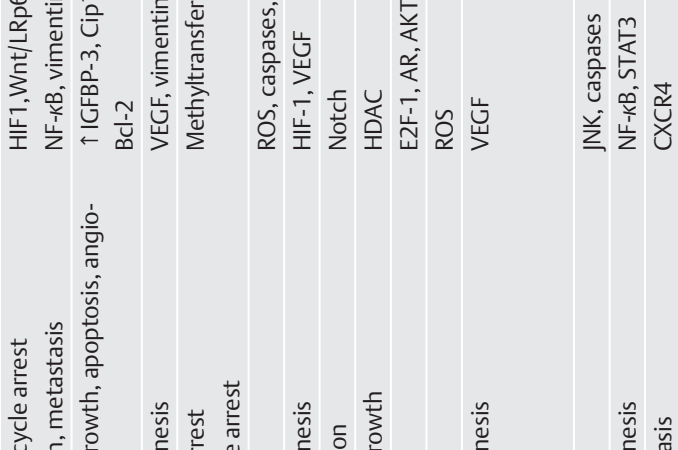

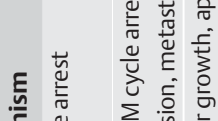

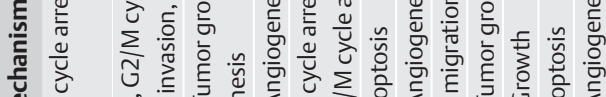

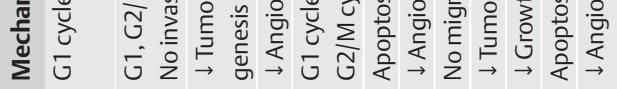

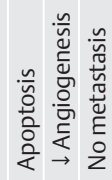

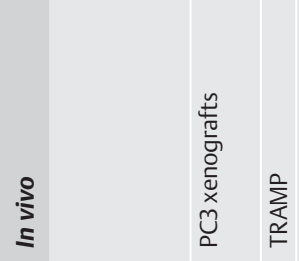

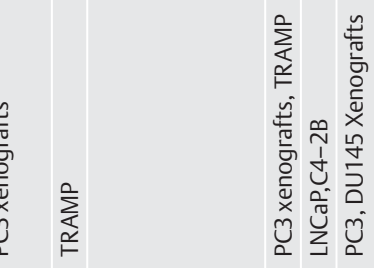

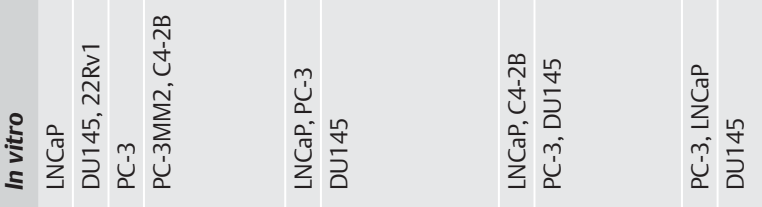

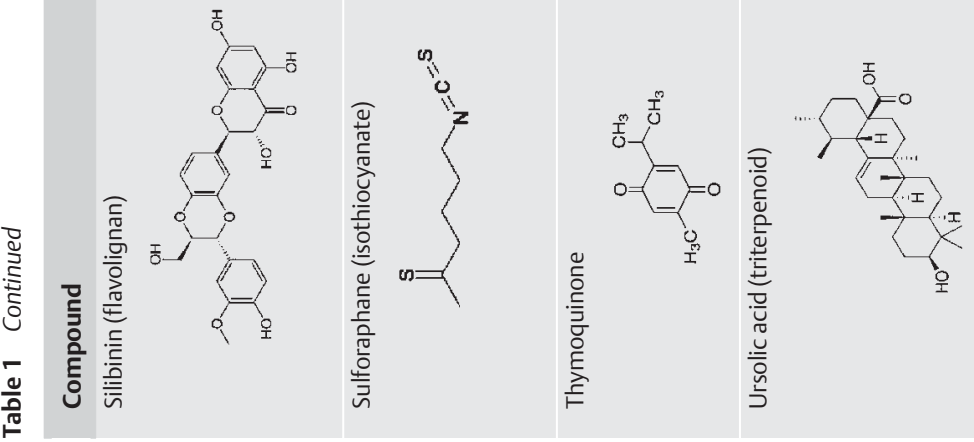


ducted in order to clarify whether these compounds can exert their effects in physiologic concentrations or have a combinational effect when administered with the traditional chemotherapeutic agents in order to determine if they are possible candidates for clinical trials.

\section{Conflict of Interest}

$\nabla$

The authors declare that no conflict of interest or any financial disclosure exists.

\section{References}

1 Harvey AL, Cree IA. High-throughput screening of natural products for cancer therapy. Planta Med 2010; 76: 1080-1086

2 Fulda S. Modulation of apoptosis by natural products for cancer therapy. Planta Med 2010; 76: 1075-1079

3 Mukhtar E, Adhami VM, Khan N, Mukhtar H. Apoptosis and autophagy induction as mechanism of cancer prevention by naturally occurring dietary agents. Curr Drug Targets 2012; 13: 1831-1841

4 Mabry T, Markham KR, Thomas MB. The systematic identification of flavonoids. Berlin, Heidelberg: Springer-Verlag; 1970: 1-345

5 Sak K. Cytotoxicity of dietary flavonoids on different human cancer types. Pharmacogn Rev 2014; 8: 122-146

6 Gupta S, Afaq F, Mukhtar H. Involvement of nuclear factor-kappa B, Bax and $\mathrm{Bcl}-2$ in induction of cell cycle arrest and apoptosis by apigenin in human prostate carcinoma cells. Oncogene 2002; 21: 3727-3738

7 Shukla S, Gupta S. Molecular mechanisms for apigenin-induced cellcycle arrest and apoptosis of hormone refractory human prostate carcinoma DU145 cells. Mol Carcinog 2004; 39: 114-126

8 Shukla S, Gupta S. Apigenin suppresses insulin-like growth factor I receptor signaling in human prostate cancer: an in vitro and in vivo study. Mol Carcinog 2009; 48: 243-252

9 Franzen CA, Amargo E, Todorovic V, Desai BV, Huda S, Mirzoeva S, Chiu K, Grzybowski BA, Chew TL, Green KJ, Pelling JC. The chemopreventive bioflavonoid apigenin inhibits prostate cancer cell motility through the focal adhesion kinase/Src signaling mechanism. Cancer Prev Res (Phila) 2009; 2: 830-841

10 Pandey M, Kaur P, Shukla S, Abbas A, Fu P, Gupta S. Plant flavone apigenin inhibits HDAC and remodels chromatin to induce growth arrest and apoptosis in human prostate cancer cells: in vitro and in vivo study. Mol Carcinog 2012; 51: 952-962

11 Shukla S, Gupta S. Apigenin-induced prostate cancer cell death is initiated by reactive oxygen species and p53 activation. Free Radic Biol Med 2008; 44: 1833-1845

12 Mirzoeva S, Franzen CA, Pelling JC. Apigenin inhibits TGF-beta-induced VEGF expression in human prostate carcinoma cells via a Smad2/3and Src-dependent mechanism. Mol Carcinog 2014; 53: 598-609

13 Shukla S, Gupta S. Molecular targets for apigenin-induced cell cycle arrest and apoptosis in prostate cancer cell xenograft. Mol Cancer Ther 2006; 5: 843-852

14 Shukla S, Bhaskaran N, Babcook MA, Fu P, Maclennan GT, Gupta S. Apigenin inhibits prostate cancer progression in TRAMP mice via targeting PI3K/Akt/FoxO pathway. Carcinogenesis 2014; 35: 452-460

15 Qinghaosu Antimalarial Coordinating Research Group. Antimalaria studies on Qinghaosu. Chin Med J (Engl) 1979; 12: 811-816

16 Willoughby JA sen., Sundar SN, Cheung M, Tin AS, Modiano J, Firestone GL. Artemisinin blocks prostate cancer growth and cell cycle progression by disrupting $\mathrm{Sp} 1$ interactions with the cyclin-dependent kinase4 (CDK4) promoter and inhibiting CDK4 gene expression. J Biol Chem 2009; 284: 2203-2213

17 Huang XF, Yuan D, Zhang CC, Zhang XP. [Artesunate induces prostate cancer cell line PC-3 differentiation and cell cycle arrest]. Zhong Xi Yi Jie He Xue Bao 2008; 6: 591-594

18 He Q Shi J, Shen XL, An J, Sun H, Wang L, Hu YJ, Sun Q Fu LC, Sheikh MS, Huang $Y$. Dihydroartemisinin upregulates death receptor 5 expression and cooperates with TRAIL to induce apoptosis in human prostate cancer cells. Cancer Biol Ther 2010; 9: 819-824

19 Morrissey C, Gallis B, Solazzi JW, Kim BJ, Gulati R, Vakar-Lopez F, Goodlett $D R$, Vessella RL, Sasaki T. Effect of artemisinin derivatives on apoptosis and cell cycle in prostate cancer cells. Anticancer Drugs 2010; 21: 423432
20 Koda A, Nagai H, Wada H. [Pharmacological actions of baicalin and baicalein. 1. On active anaphylaxis]. Nihon Yakurigaku Zasshi 1970; 66: 194-213

21 Parajuli P, Joshee N, Rimando AM, Mittal S, Yadav AK. In vitro antitumor mechanisms of various Scutellaria extracts and constituent flavonoids. Planta Med 2009; 75: 41-48

22 Chen S, Ruan Q, Bedner E, Deptala A, Wang X, Hsieh TC, Traganos F, Darzynkiewicz Z. Effects of the flavonoid baicalin and its metabolite baicalein on androgen receptor expression, cell cycle progression and apoptosis of prostate cancer cell lines. Cell Prolif 2001; 34: 293-304

$23 \mathrm{Gu} Z \mathrm{Z}$, Sun YH, Xu CL, Liu Y. [Study of baicalin in inducing prostate cancer cell line DU145 apoptosis in vitro]. Zhongguo Zhong Yao Za Zhi 2005; 30: 63-66

24 Petlichnaia LI. [Chemistry of the alkaloid berberine and its derivatives] Farm Zh 1975; 30: 22-28

25 Mantena SK, Sharma SD, Katiyar SK. Berberine, a natural product, induces G1-phase cell cycle arrest and caspase-3-dependent apoptosis in human prostate carcinoma cells. Mol Cancer Ther 2006; 5: 296-308

26 Li J, Cao B, Liu X, Fu X, Xiong Z, Chen L, Sartor O, Dong Y, Zhang H. Berberine suppresses androgen receptor signaling in prostate cancer. Mol Cancer Ther 2011; 10: 1346-1356

27 Zhang $Q$, Zhang C, Yang X, Yang B, Wang J, Kang Y, Wang Z, Li D, Huang G, Ma Z, Sun X, Cai J, Tao G, Dai S, Mao W, Ma J. Berberine inhibits the expression of hypoxia induction factor-1alpha and increases the radiosensitivity of prostate cancer. Diagn Pathol 2014; 9: 98

28 Yasue M, Borodzinski K, Kaiya T. [Syntheses of nitrogen-containing triterpenes. III. Derivatives of betulinic acid and oleanolic acid (author's transl)]. Yakugaku Zasshi 1974; 94: 1468-1474

29 Chintharlapalli S, Papineni S, Ramaiah SK, Safe S. Betulinic acid inhibits prostate cancer growth through inhibition of specificity protein transcription factors. Cancer Res 2007; 67: 2816-2823

30 Rabi T, Shukla S, Gupta S. Betulinic acid suppresses constitutive and TNFalpha-induced NF-kappaB activation and induces apoptosis in human prostate carcinoma PC-3 cells. Mol Carcinog 2008; 47: 964-973

31 Reiner T, Parrondo R, de Las Pozas A, Palenzuela D, Perez-Stable C. Betulinic acid selectively increases protein degradation and enhances prostate cancer-specific apoptosis: possible role for inhibition of deubiquitinase activity. PLoS One 2013; 8: 56234

32 Nelson EK. The constitution of capsaicin, the pungent principle of capsicum. J Am Chem Soc 1919; 41: 1115-1121

33 Sanchez AM, Sanchez MG, Malagarie-Cazenave S, Olea N, Diaz-Laviada I. Induction of apoptosis in prostate tumor PC-3 cells and inhibition of xenograft prostate tumor growth by the vanilloid capsaicin. Apoptosis 2006; 11: 89-99

34 Sanchez AM, Malagarie-Cazenave S, Olea N, Vara D, Chiloeches A, DiazLaviada I. Apoptosis induced by capsaicin in prostate PC-3 cells involves ceramide accumulation, neutral sphingomyelinase, and JNK activation. Apoptosis 2007; 12: 2013-2024

35 Mori A, Lehmann S, O'Kelly J, Kumagai T, Desmond JC, Pervan M, McBride WH, Kizaki M, Koeffler HP. Capsaicin, a component of red peppers, inhibits the growth of androgen-independent, p 53 mutant prostate cancer cells. Cancer Res 2006; 66: 3222-3229

36 Schraufstatter E, Bernt $H$. Antibacterial action of curcumin and related compounds. Nature 1949; 164: 456

37 Dorai T, Gehani N, Katz A. Therapeutic potential of curcumin in human prostate cancer. II. Curcumin inhibits tyrosine kinase activity of epidermal growth factor receptor and depletes the protein. Mol Urol 2000; 4: $1-6$

38 Hilchie AL, Furlong SJ, Sutton K, Richardson A, Robichaud MR, Giacomantonio CA, Ridgway ND, Hoskin DW. Curcumin-induced apoptosis in PC3 prostate carcinoma cells is caspase-independent and involves cellular ceramide accumulation and damage to mitochondria. Nutr Cancer 2010; 62: 379-389

39 Mukhopadhyay A, Bueso-Ramos C, Chatterjee D, Pantazis P, Aggarwal $B B$. Curcumin downregulates cell survival mechanisms in human prostate cancer cell lines. Oncogene 2001; 20: 7597-7609

40 Teiten MH, Gaascht F, Cronauer M, Henry E, Dicato M, Diederich M. Antiproliferative potential of curcumin in androgen-dependent prostate cancer cells occurs through modulation of the Wingless signaling pathway. Int J Oncol 2011; 38: 603-611

41 Santel T, Pflug G, Hemdan NY, Schafer A, Hollenbach M, Buchold M, Hintersdorf A, Lindner I, Otto A, Bigl M, Oerlecke I, Hutschenreuther A, Sack U, Huse K, Groth M, Birkemeyer C, Schellenberger W, Gebhardt R, Platzer M, Weiss T, Vijayalakshmi MA, Kruger M, Birkenmeier G. Curcumin in- 
hibits glyoxalase 1 : a possible link to its anti-inflammatory and antitumor activity. PLoS One 2008; 3: 3508

42 Hong JH, Ahn KS, Bae E, Jeon SS, Choi HY. The effects of curcumin on the invasiveness of prostate cancer in vitro and in vivo. Prostate Cancer Prostatic Dis 2006; 9: 147-152

43 Killian PH, Kronski E, Michalik KM, Barbieri O, Astigiano S, Sommerhoff $C P$, Pfeffer $U$, Nerlich AG, Bachmeier BE. Curcumin inhibits prostate cancer metastasis in vivo by targeting the inflammatory cytokines CXCL1 and -2. Carcinogenesis 2012; 33: 2507-2519

44 Thangapazham RL, Puri A, Tele S, Blumenthal R, Maheshwari RK. Evaluation of a nanotechnology-based carrier for delivery of curcumin in prostate cancer cells. Int J Oncol 2008; 32: 1119-1123

45 Labow RS, Layne DS. The formation of glucosides of isoflavones and of some other phenols by rabbit liver microsomal fractions. Biochem J 1972; 128: 491-497

46 Rabiau N, Kossai M, Braud M, Chalabi N, Satih S, Bignon YJ, Bernard-Gallon DJ. Genistein and daidzein act on a panel of genes implicated in cell cycle and angiogenesis by polymerase chain reaction arrays in human prostate cancer cell lines. Cancer Epidemiol 2010; 34: 200-206

47 Vardi A, Bosviel R, Rabiau N, Adjakly M, Satih S, Dechelotte P, Boiteux JP, Fontana L, Bignon YJ, Guy L, Bernard-Gallon DJ. Soy phytoestrogens modify DNA methylation of GSTP1, RASSF1A, EPH2 and BRCA1 promoter in prostate cancer cells. In Vivo 2010; 24: 393-400

48 Ribéreau-Gayon J, Ribéreau-Gayon P. The Anthocyans and Leucoanthocyans of Grapes and Wines. Am J Enol Viticult 1958; 9: 1-9

49 Syed DN, Suh Y, Afaq F, Mukhtar H. Dietary agents for chemoprevention of prostate cancer. Cancer Lett 2008; 265: 167-176

50 Hafeez BB, Siddiqui IA, Asim M, Malik A, Afaq F, Adhami VM, Saleem M, Din $M$, Mukhtar $H$. A dietary anthocyanidin delphinidin induces apoptosis of human prostate cancer PC3 cells in vitro and in vivo: involvement of nuclear factor-kappaB signaling. Cancer Res 2008; 68: 85648572

51 Nierenstein $M$. The formation of ellagic acid from galloyl-glycine by Penicillium. Biochem J 1915; 9: 240-244

52 Vanella L, Di Giacomo C, Acquaviva R, Barbagallo I, Cardile V, Kim DH, Abraham NG, Sorrenti V. Apoptotic markers in a prostate cancer cell line: effect of ellagic acid. Oncol Rep 2013; 30: 2804-2810

53 Pitchakarn P, Chewonarin T, Ogawa K, Suzuki S, Asamoto M, Takahashi S, Shirai T, Limtrakul $P$. Ellagic acid inhibits migration and invasion by prostate cancer cell lines. Asian Pac J Cancer Prev 2013; 14: 2859-2863

54 Kada T, Kaneko K, Matsuzaki S, Matsuzaki T, Hara Y. Detection and chemical identification of natural bio-antimutagens. A case of the green tea factor. Mutat Res 1985; 150: 127-132

55 Gupta S, Ahmad N, Nieminen AL, Mukhtar H. Growth inhibition, cellcycle dysregulation, and induction of apoptosis by green tea constituent (-)-epigallocatechin-3-gallate in androgen-sensitive and androgen-insensitive human prostate carcinoma cells. Toxicol Appl Pharmacol 2000; 164: 82-90

56 Gupta S, Hussain T, Mukhtar H. Molecular pathway for (-)-epigallocatechin-3-gallate-induced cell cycle arrest and apoptosis of human prostate carcinoma cells. Arch Biochem Biophys 2003; 410: 177-185

57 Hastak K, Gupta S, Ahmad N, Agarwal MK, Agarwal ML, Mukhtar H. Role of p 53 and NF-kappaB in epigallocatechin-3-gallate-induced apoptosis of LNCaP cells. Oncogene 2003; 22: 4851-4859

58 Albrecht DS, Clubbs EA, Ferruzzi M, Bomser JA. Epigallocatechin-3-gallate (EGCG) inhibits PC-3 prostate cancer cell proliferation via MEK-independent ERK1/2 activation. Chem Biol Interact 2008; 171: 89-95

59 Hussain T, Gupta S, Adhami VM, Mukhtar H. Green tea constituent epigallocatechin-3-gallate selectively inhibits COX-2 without affecting COX-1 expression in human prostate carcinoma cells. Int J Cancer 2005; 113: 660-669

60 Siddiqui IA, Asim M, Hafeez BB, Adhami VM, Tarapore RS, Mukhtar H. Green tea polyphenol EGCG blunts androgen receptor function in prostate cancer. FASEB J 2011; 25: 1198-1207

61 Harper CE, Patel BB, Wang J, Eltoum IA, Lamartiniere CA. Epigallocatechin-3-Gallate suppresses early stage, but not late stage prostate cancer in TRAMP mice: mechanisms of action. Prostate 2007; 67: 15761589

62 Khan N, Bharali DJ, Adhami VM, Siddiqui IA, Cui H, Shabana SM, Mousa $S A$, Mukhtar H. Oral administration of naturally occurring chitosanbased nanoformulated green tea polyphenol EGCG effectively inhibits prostate cancer cell growth in a xenograft model. Carcinogenesis 2014; 35: $415-423$

63 Herzig J. [Studies on Quercetin and its derivatives, treatise VII]. Monatsh Chem 1891; 12: 177-190
64 Khan N, Asim M, Afaq F, Abu Zaid M, Mukhtar H. A novel dietary flavonoid fisetin inhibits androgen receptor signaling and tumor growth in athymic nude mice. Cancer Res 2008; 68: 8555-8563

65 Chien CS, Shen KH, Huang JS, Ko SC, Shih YW. Antimetastatic potential of fisetin involves inactivation of the PI3K/Akt and JNK signaling pathways with downregulation of MMP-2/9 expressions in prostate cancer PC-3 cells. Mol Cell Biochem 2010; 333: 169-180

66 Szliszka E, Helewski KJ, Mizgala E, Krol W. The dietary flavonol fisetin enhances the apoptosis-inducing potential of TRAIL in prostate cancer cells. Int J Oncol 2011; 39: 771-779

67 Adhami VM, Syed DN, Khan N, Mukhtar H. Dietary flavonoid fisetin: a novel dual inhibitor of PI3K/Akt and mTOR for prostate cancer management. Biochem Pharmacol 2012; 84: 1277-1281

68 Ye Y, Hou R, Chen J, Mo L, Zhang J, Huang Y, Mo Z. Formononetin-induced apoptosis of human prostate cancer cells through ERK1/2 mitogen-activated protein kinase inactivation. Horm Metab Res 2012; 44: 263-267

69 Huang WJ, Bi LY, Li ZZ, Zhang X, Ye Y. Formononetin induces the mitochondrial apoptosis pathway in prostate cancer cells via downregulation of the IGF-1/IGF-1R signaling pathway. Pharm Biol 2014; 52: 466-470

70 Zhang X, Bi L, Ye Y, Chen J. Formononetin induces apoptosis in PC-3 prostate cancer cells through enhancing the $\mathrm{Bax} / \mathrm{Bcl}-2$ ratios and regulating the p 38/Akt pathway. Nutr Cancer 2014; 66: 656-661

71 Liu XJ, Li YQ Chen QY, Xiao SJ, Zeng SE. Up-regulating of RASD1 and apoptosis of DU-145 human prostate cancer cells induced by formononetin in vitro. Asian Pac J Cancer Prev 2014; 15: 2835-2839

72 Henri B. Observations sur la préparation et la purification de l'acide gallique, et sur l'existence d'un acide nouveau dans la noix de galle. Ann Chim Physique 1818; 9: 181-184

73 Chen HM, Wu YC, Chia YC, Chang FR, Hsu HK, Hsieh YC, Chen CC, Yuan SS. Gallic acid, a major component of Toona sinensis leaf extracts, contains a ROS-mediated anti-cancer activity in human prostate cancer cells. Cancer Lett 2009; 286: 161-171

74 Liu KC, Huang AC, Wu PP, Lin HY, Chueh FS, Yang JS, Lu CC, Chiang JH, Meng M, Chung JG. Gallic acid suppresses the migration and invasion of PC-3 human prostate cancer cells via inhibition of matrix metalloproteinase-2 and - 9 signaling pathways. Oncol Rep 2011; 26: 177-184

75 Raina K, Rajamanickam S, Deep G, Singh M, Agarwal R, Agarwal C. Chemopreventive effects of oral gallic acid feeding on tumor growth and progression in TRAMP mice. Mol Cancer Ther 2008; 7: 1258-1267

76 Kaur M, Velmurugan B, Rajamanickam S, Agarwal R, Agarwal C. Gallic acid, an active constituent of grape seed extract, exhibits anti-proliferative, pro-apoptotic and anti-tumorigenic effects against prostate carcinoma xenograft growth in nude mice. Pharm Res 2009; 26: 2133 2140

77 Liesenklas $W$, Auterhoff $H$. [The constitution of gambogic acid and its isomerization. 4. Chemistry of gum-resin]. Arch Pharm Ber Dtsch Pharm Ges 1966; 299: 797-798

78 Lu L, Tang D, Wang L, Huang LQ Jiang GS, Xiao XY, Zeng FQ. Gambogic acid inhibits TNF-alpha-induced invasion of human prostate cancer PC3 cells in vitro through PI3K/Akt and NF-kappaB signaling pathways. Acta Pharmacol Sin 2012; 33: 531-541

79 Yi T, Yi Z, Cho SG, Luo J, Pandey MK, Aggarwal BB, Liu M. Gambogic acid inhibits angiogenesis and prostate tumor growth by suppressing vascular endothelial growth factor receptor 2 signaling. Cancer Res 2008; 68: $1843-1850$

80 Walter ED. Genistin and its aglucone, genistein, from soybeans. JACS 1941; 63: 3273-3276

81 Rokhlin OW, Cohen MB. Differential sensitivity of human prostatic cancer cell lines to the effects of protein kinase and phosphatase inhibitors. Cancer Lett 1995; 98: 103-110

82 Lee J, Ju J, Park S, Hong SJ, Yoon S. Inhibition of IGF-1 signaling by genistein: modulation of E-cadherin expression and downregulation of beta-catenin signaling in hormone refractory PC-3 prostate cancer cells. Nutr Cancer 2012; 64: 153-162

83 Virk-Baker MK, Nagy TR, Barnes S. Role of phytoestrogens in cancer therapy. Planta Med 2010; 76: 1132-1142

84 Hirata H, Hinoda Y, Shahryari V, Deng G, Tanaka Y, Tabatabai ZL, Dahiya $R$. Genistein downregulates onco-miR-1260b and upregulates SFRP1 and Smad4 via demethylation and histone modification in prostate cancer cells. Br J Cancer 2014; 110: 1645-1654 
85 Chiyomaru T, Yamamura S, Fukuhara S, Yoshino H, Kinoshita T, Majid S, Saini S, Chang I, Tanaka Y, Enokida H, Seki N, Nakagawa M, Dahiya R. Genistein inhibits prostate cancer cell growth by targeting miR-34a and oncogenic HOTAIR. PLoS One 2013; 8: 70372

86 Kazi A, Daniel KG, Smith DM, Kumar NB, Dou QP. Inhibition of the proteasome activity, a novel mechanism associated with the tumor cell apoptosis-inducing ability of genistein. Biochem Pharmacol 2003; 66: 965-976

87 Gao S, Liu GZ, Wang Z. Modulation of androgen receptor-dependent transcription by resveratrol and genistein in prostate cancer cells. Prostate 2004; 59: 214-225

88 Mahmoud AM, Zhu T, Parray A, Siddique HR, Yang W, Saleem M, Bosland MC. Differential effects of genistein on prostate cancer cells depend on mutational status of the androgen receptor. PLoS One 2013; 8: 78479

89 Li Y, Sarkar FH. Down-regulation of invasion and angiogenesis-related genes identified by cDNA microarray analysis of PC3 prostate cancer cells treated with genistein. Cancer Lett 2002; 186: 157-164

90 Zhang L, Li L, Jiao M, Wu D, Wu K, Li X, Zhu G, Yang L, Wang X, Hsieh JT, He D. Genistein inhibits the stemness properties of prostate cancer cells through targeting Hedgehog-Gli1 pathway. Cancer Lett 2012; 323: 48-57

91 Adjakly M, Bosviel R, Rabiau N, Boiteux JP, Bignon YJ, Guy L, BernardGallon D. DNA methylation and soy phytoestrogens: quantitative study in DU-145 and PC-3 human prostate cancer cell lines. Epigenomics 2011; 3: 795-803

92 Pollard M, Luckert PH. Influence of isoflavones in soy protein isolates on development of induced prostate-related cancers in L-W rats. Nutr Cancer 1997; 28: 41-45

93 Mentor-Marcel R, Lamartiniere CA, Eltoum IE, Greenberg NM, Elgavish $A$. Genistein in the diet reduces the incidence of poorly differentiated prostatic adenocarcinoma in transgenic mice (TRAMP). Cancer Res 2001; 61: 6777-6782

94 Lazarevic B, Boezelijn G, Diep LM, Kvernrod K, Ogren O, Ramberg H, Moen A, Wessel N, Berg RE, Egge-Jacobsen W, Hammarstrom C, Svindland A, Kucuk O, Saatcioglu F, Tasken KA, Karlsen SJ. Efficacy and safety of short-term genistein intervention in patients with localized prostate cancer prior to radical prostatectomy: a randomized, placebocontrolled, double-blind Phase 2 clinical trial. Nutr Cancer 2011; 63: 889-898

95 Phan V, Walters J, Brownlow B, Elbayoumi T. Enhanced cytotoxicity of optimized liposomal genistein via specific induction of apoptosis in breast, ovarian and prostate carcinomas. J Drug Target 2013; 21: 1001-1011

96 Zhang S, Wang Y, Chen Z, Kim S, Iqbal S, Chi A, Ritenour C, Wang YA, Kucuk $O, W u D$. Genistein enhances the efficacy of cabazitaxel chemotherapy in metastatic castration-resistant prostate cancer cells. Prostate 2013; 73: 1681-1689

97 Hwang YW, Kim SY, Jee SH, Kim YN, Nam CM. Soy food consumption and risk of prostate cancer: a meta-analysis of observational studies. Nutr Cancer 2009; 61: 598-606

98 Zhao YQ Yuan CL. [Chemical constituents of the fruit of Panax ginseng C. A. Meyer]. Zhongguo Zhong Yao Za Zhi 1993; 18: 296-297, 319

99 Kim HS, Lee EH, Ko SR, Choi KJ, Park JH, Im DS. Effects of ginsenosides $\operatorname{Rg} 3$ and Rh2 on the proliferation of prostate cancer cells. Arch Pharm Res 2004; 27: 429-435

100 Pan XY, Guo H, Han J, Hao F, An Y, Xu Y, Xiaokaiti Y, Pan Y, Li XJ. Ginsenoside $\mathrm{Rg} 3$ attenuates cell migration via inhibition of aquaporin $1 \mathrm{ex}-$ pression in PC-3 M prostate cancer cells. Eur J Pharmacol 2012; 683: 27-34

101 Kim SM, Lee SY, Cho JS, Son SM, Choi SS, Yun YP, Yoo HS, Yoon do Y, Oh $K W$, Han SB, Hong JT. Combination of ginsenoside Rg3 with docetaxel enhances the susceptibility of prostate cancer cells via inhibition of NF-kappaB. Eur J Pharmacol 2010; 631: 1-9

102 Chen YJ, Xie H, Pei YP, Xu SX, Yao XS. [Isolation and identification of the anti-tumor constituent, ginsenoside-Rh2]. Zhong Yao Tong Bao 1988; 13: $40-42,64$

103 Xie X, Eberding A, Madera C, Fazli L, Jia W, Goldenberg L, Gleave M, Guns $E S$. Rh2 synergistically enhances paclitaxel or mitoxantrone in prostate cancer models. J Urol 2006; 175: 1926-1931

104 Musende AG, Eberding A, Wood C, Adomat H, Fazli L, Hurtado-Coll A, Jia W, Bally MB, Guns ET. Pre-clinical evaluation of Rh2 in PC-3 human xenograft model for prostate cancer in vivo: formulation, pharmacokinetics, biodistribution and efficacy. Cancer Chemother Pharmacol 2009; 64: 1085-1095
105 Wang W, Rayburn ER, Hao M, Zhao Y, Hill DL, Zhang R, Wang H. Experimental therapy of prostate cancer with novel natural product anticancer ginsenosides. Prostate 2008; 68: 809-819

106 Wang W, Wang H, Rayburn ER, Zhao Y, Hill DL, Zhang R. 20(S)-25methoxyl-dammarane-3beta, 12beta, 20-triol, a novel natural product for prostate cancer therapy: activity in vitro and in vivo and mechanisms of action. Br J Cancer 2008; 98: 792-802

107 Seon MR, Lim SS, Choi HJ, Park SY, Cho HJ, Kim JK, Kim J, Kwon DY, Park $J H$. Isoangustone A present in hexane/ethanol extract of Glycyrrhiza uralensis induces apoptosis in DU145 human prostate cancer cells via the activation of DR4 and intrinsic apoptosis pathway. Mol Nutr Food Res 2010; 54: 1329-1339

108 Seon MR, Park SY, Kwon SJ, Lim SS, Choi HJ, Park H, Lim do Y, Kim JS, Lee CH, Kim J, Park JH. Hexane/ethanol extract of Glycyrrhiza uralensis and its active compound isoangustone A induce G1 cycle arrest in DU145 human prostate and $4 \mathrm{~T} 1$ murine mammary cancer cells. J Nutr Biochem 2012; 23: 85-92

109 Park SY, Lim SS, Kim JK, Kang IJ, Kim JS, Lee C, Kim J, Park JH. Hexaneethanol extract of Glycyrrhiza uralensis containing licoricidin inhibits the metastatic capacity of DU145 human prostate cancer cells. Br J Nutr 2010; 104: 1272-1282

110 Hatano T, Yasuhara T, Fukuda T, Noro T, Okuda T. Phenolic constituents of licorice. II. Structures of licopyranocoumarin, licoarylcoumarin and glisoflavone, and inhibitory effects of licorice phenolics on xanthine oxidase. Chem Pharm Bull (Tokyo) 1989; 37: 3005-3009

111 Fu Y, Hsieh TC, Guo J, Kunicki J, Lee MY, Darzynkiewicz Z, Wu JM. Licochalcone-A, a novel flavonoid isolated from licorice root (Glycyrrhiza glabra), causes G2 and late-G1 arrests in androgen-independent PC-3 prostate cancer cells. Biochem Biophys Res Commun 2004; 322: $263-$ 270

112 Yo YT, Shieh GS, Hsu KF, Wu CL, Shiau AL. Licorice and licochalcone-A induce autophagy in LNCaP prostate cancer cells by suppression of Bcl-2 expression and the mTOR pathway. J Agric Food Chem 2009; 57: 8266-8273

113 Shetty AV, Thirugnanam S, Dakshinamoorthy G, Samykutty A, Zheng G, Chen A, Bosland MC, Kajdacsy-Balla A, Gnanasekar M. 18alpha-glycyrrhetinic acid targets prostate cancer cells by down-regulating inflammation-related genes. Int J Oncol 2011; 39: 635-640

114 Hawthorne S, Gallagher S. Effects of glycyrrhetinic acid and liquorice extract on cell proliferation and prostate-specific antigen secretion in LNCaP prostate cancer cells. J Pharm Pharmacol 2008; 60: 661-666

115 Withers WA, Carruth FE. Gossypol-a toxic substance in cottonseed. A preliminary note. Science 1915; 41: 324

116 Jiang J, Ye W, Lin YC. Gossypol inhibits the growth of MAT-LyLu prostate cancer cells by modulation of TGFbeta/Akt signaling. Int J Mol Med 2009; 24: 69-75

117 Zhang M, Liu H, Tian Z, Griffith BN, Ji M, Li QQ. Gossypol induces apoptosis in human $\mathrm{PC}-3$ prostate cancer cells by modulating caspase-dependent and caspase-independent cell death pathways. Life Sci 2007; 80: 767-774

118 Lian J, Karnak D, Xu L. The Bcl-2-Beclin 1 interaction in (-)-gossypolinduced autophagy versus apoptosis in prostate cancer cells. Autophagy 2010; 6: 1201-1203

119 Jiang J, Slivova V, Jedinak A, Sliva D. Gossypol inhibits growth, invasiveness, and angiogenesis in human prostate cancer cells by modulating NF-kappaB/AP-1 dependent- and independent-signaling. Clin Exp Metastasis 2012; 29: 165-178

120 Pang X, Wu Y, Lu B, Chen J, Wang J, Yi Z, Qu W, Liu M. (-)-Gossypol suppresses the growth of human prostate cancer xenografts via modulating VEGF signaling-mediated angiogenesis. Mol Cancer Ther 2011; 10: 795-805

121 Cengiz E, Karaca B, Kucukzeybek Y, Gorumlu G, Gul MK, Erten C, Atmaca $H$, Uzunoglu S, Karabulut B, Sanli UA, Uslu R. Overcoming drug resistance in hormone- and drug-refractory prostate cancer cell line, PC-3 by docetaxel and gossypol combination. Mol Biol Rep 2010; 37: 12691277

122 Lian J, Ni Z, Dai X, Su C, Smith AR, Xu L, He F. Sorafenib sensitizes (-)-gossypol-induced growth suppression in androgen-independent prostate cancer cells via Mcl- 1 inhibition and Bak activation. Mol Cancer Ther 2012; 11: 416-426

123 Liu G, Kelly WK, Wilding G, Leopold L, Brill K, Somer B. An open-label, multicenter, phase I/II study of single-agent AT-101 in men with castrate-resistant prostate cancer. Clin Cancer Res 2009; 15: 3172-3176 
124 Hagg-Berrurier $M$, Duquenois $P$. [Extraction and physicochemical characterization of the luteolin in the flowers of the hawkweed Hieracium pilosella L]. C R Hebd Seances Acad Sci 1962; 254: 3419-3421

125 Horinaka M, Yoshida T, Shiraishi T, Nakata S, Wakada M, Nakanishi R, Nishino H, Matsui H, Sakai T. Luteolin induces apoptosis via death receptor 5 upregulation in human malignant tumor cells. Oncogene 2005; 24: 7180-7189

126 Fang J, Zhou Q Shi XL, Jiang BH. Luteolin inhibits insulin-like growth factor 1 receptor signaling in prostate cancer cells. Carcinogenesis 2007; 28: 713-723

127 Shoulars K, Rodriguez MA, Thompson T, Markaverich BM. Regulation of cell cycle and RNA transcription genes identified by microarray analysis of PC-3 human prostate cancer cells treated with luteolin. J Steroid Biochem Mol Biol 2010; 118: 41-50

128 Pratheeshkumar P, Son YO, Budhraja A, Wang X, Ding S, Wang L, Hitron A, Lee JC, Kim D, Divya SP, Chen G, Zhang Z, Luo J, Shi X. Luteolin inhibits human prostate tumor growth by suppressing vascular endothelial growth factor receptor 2-mediated angiogenesis. PLoS One 2012; 7: 52279

129 Matlack MB, Sando CE. A contribution to the chemistry of tomato pigments. The coloring matter in American red and purple tomatoes ( $\mathrm{Ly}$ copersicum esculentum). J Biol Chem 1934; 104: 407-414

130 Hantz HL, Young LF, Martin KR. Physiologically attainable concentrations of lycopene induce mitochondrial apoptosis in LNCaP human prostate cancer cells. Exp Biol Med (Maywood) 2005; 230: 171-179

131 Yang CM, Lu IH, Chen HY, Hu ML. Lycopene inhibits the proliferation of androgen-dependent human prostate tumor cells through activation of PPARgamma-LXRalpha-ABCA1 pathway. J Nutr Biochem 2012; 23: 8-17

132 Yang CM, Yen YT, Huang CS, Hu ML. Growth inhibitory efficacy of lycopene and beta-carotene against androgen-independent prostate tumor cells xenografted in nude mice. Mol Nutr Food Res 2011; 55: 606-612

133 Palozza P, Colangelo M, Simone R, Catalano A, Boninsegna A, Lanza P, Monego $G$, Ranelletti FO. Lycopene induces cell growth inhibition by altering mevalonate pathway and Ras signaling in cancer cell lines. Carcinogenesis 2010; 31: 1813-1821

134 Ivanov NI, Cowell SP, Brown P, Rennie PS, Guns ES, Cox ME. Lycopene differentially induces quiescence and apoptosis in androgen-responsive and -independent prostate cancer cell lines. Clin Nutr 2007; 26 : 252-263

135 Goo YA, Li Z, Pajkovic N, Shaffer S, Taylor G, Chen J, Campbell D, Arnstein $L$, Goodlett $D R$, van Breemen $R B$. Systematic investigation of lycopene effects in LNCaP cells by use of novel large-scale proteomic analysis software. Proteomics Clin Appl 2007; 1: 513-523

136 Konijeti R, Henning S, Moro A, Sheikh A, Elashoff D, Shapiro A, Ku M, Said JW, Heber D, Cohen P, Aronson WJ. Chemoprevention of prostate cancer with lycopene in the TRAMP model. Prostate 2010; 70: 15471554

137 Mohanty NK, Saxena S, Singh UP, Goyal NK, Arora RP. Lycopene as a chemopreventive agent in the treatment of high-grade prostate intraepithelial neoplasia. Urol Oncol 2005; 23: 383-385

138 Barber NJ, Zhang X, Zhu G, Pramanik R, Barber JA, Martin FL, Morris JD, Muir GH. Lycopene inhibits DNA synthesis in primary prostate epithelial cells in vitro and its administration is associated with a reduced prostate-specific antigen velocity in a phase II clinical study. Prostate Cancer Prostatic Dis 2006; 9: 407-413

139 Bowen P, Chen L, Stacewicz-Sapuntzakis M, Duncan C, Sharifi R, Ghosh L, Kim HS, Christov-Tzelkov K, van Breemen R. Tomato sauce supplementation and prostate cancer: lycopene accumulation and modulation of biomarkers of carcinogenesis. Exp Biol Med (Maywood) 2002; 227: 886-893

140 Fujita M, Itokawa H, Sashida Y. [Studies on the components of Magnolia obovata Thunb. 3. Occurrence of magnolol and honokiol in M. obovata and other allied plants]. Yakugaku Zasshi 1973; 93: 429-434

141 Hahm ER, Arlotti JA, Marynowski SW, Singh SV. Honokiol, a constituent of oriental medicinal herb Magnolia officinalis, inhibits growth of PC-3 xenografts in vivo in association with apoptosis induction. Clin Cancer Res 2008; 14: 1248-1257

142 Hahm ER, Singh SV. Honokiol causes G0-G1 phase cell cycle arrest in human prostate cancer cells in association with suppression of retinoblastoma protein level/phosphorylation and inhibition of E2F1 transcriptional activity. Mol Cancer Ther 2007; 6: 2686-2695
143 Lee DH, Szczepanski MJ, Lee YJ. Magnolol induces apoptosis via inhibiting the EGFR/PI3K/Akt signaling pathway in human prostate cancer cells. J Cell Biochem 2009; 106: 1113-1122

144 Ito K, Iida T, Ichino K, Tsunezuka M, Hattori M, Namba T. Obovatol and obovatal, novel biphenyl ether lignans from the leaves of Magnolia obovata Thunb. Chem Pharm Bull (Tokyo) 1982; 30: 3347-3353

145 Lee SY, Yuk DY, Song HS, Yoon do Y, Jung JK, Moon DC, Lee BS, Hong JT. Growth inhibitory effects of obovatol through induction of apoptotic cell death in prostate and colon cancer by blocking of NF-kappaB. Eur J Pharmacol 2008; 582: 17-25

146 Fujita T, Masuda I, Takao S, Fujita E. Biosynthesis of natural products. Part 1. Incorporations of ent-Kaur-16-ene and ent-Kaur-16-en-15one into enmein and oridonin. J Chem Soc Perkin 1 1976; 2098-2102

147 Chen S, Gao J, Halicka HD, Huang X, Traganos F, Darzynkiewicz Z. The cytostatic and cytotoxic effects of oridonin (Rubescenin), a diterpenoid from Rabdosia rubescens, on tumor cells of different lineage. Int J Oncol 2005; 26: 579-588

148 Li X, Wang J, Ye Z, Li JC. Oridonin up-regulates expression of P21 and induces autophagy and apoptosis in human prostate cancer cells. Int J Biol Sci 2012; 8: 901-912

149 Wattenberg $L W$. Inhibition of carcinogenic effects of polycyclic hydrocarbons by benzyl isothiocyanate and related compounds. J Natl Cancer Inst 1977; 58: 395-398

150 Tang NY, Huang YT, Yu CS, Ko YC, Wu SH, Ji BC, Yang JS, Yang JL, Hsia TC, Chen YY, Chung JG. Phenethyl isothiocyanate (PEITC) promotes G2/M phase arrest via p 53 expression and induces apoptosis through caspase- and mitochondria-dependent signaling pathways in human prostate cancer DU 145 cells. Anticancer Res 2011; 31: 1691-1702

151 Yin P, Kawamura T, He M, Vanaja DK, Young CY. Phenethyl isothiocyanate induces cell cycle arrest and reduction of alpha- and beta-tubulin isotypes in human prostate cancer cells. Cell Biol Int 2009; 33: 57-64

152 Wang LG, Liu XM, Chiao JW. Repression of androgen receptor in prostate cancer cells by phenethyl isothiocyanate. Carcinogenesis 2006; 27: 2124-2132

153 Sakao K, Desineni S, Hahm ER, Singh SV. Phenethyl isothiocyanate suppresses inhibitor of apoptosis family protein expression in prostate cancer cells in culture and in vivo. Prostate 2012; 72: 1104-1116

154 Bommareddy A, Hahm ER, Xiao D, Powolny AA, Fisher AL, Jiang Y, Singh $S V$. Atg5 regulates phenethyl isothiocyanate-induced autophagic and apoptotic cell death in human prostate cancer cells. Cancer Res 2009 69: 3704-3712

155 Kim SH, Sehrawat A, Sakao K, Hahm ER, Singh SV. Notch activation by phenethyl isothiocyanate attenuates its inhibitory effect on prostate cancer cell migration. PLoS One 2011; 6: e26615

156 Xiao D, Singh SV. Phenethyl isothiocyanate inhibits angiogenesis in vitro and ex vivo. Cancer Res 2007; 67: 2239-2246

157 Xiao D, Lew KL, Zeng Y, Xiao H, Marynowski SW, Dhir R, Singh SV. Phenethyl isothiocyanate-induced apoptosis in PC-3 human prostate cancer cells is mediated by reactive oxygen species-dependent disruption of the mitochondrial membrane potential. Carcinogenesis 2006; 27: 2223-2234

158 Hudson TS, Perkins SN, Hursting SD, Young HA, Kim YS, Wang TC, Wang TT. Inhibition of androgen-responsive LNCaP prostate cancer cell tumor xenograft growth by dietary phenethyl isothiocyanate correlates with decreased angiogenesis and inhibition of cell attachment. Int J Oncol 2012; 40: 1113-1121

159 Powolny AA, Bommareddy A, Hahm ER, Normolle DP, Beumer JH, Nelson $J B$, Singh SV. Chemopreventative potential of the cruciferous vegetable constituent phenethyl isothiocyanate in a mouse model of prostate cancer. J Natl Cancer Inst 2011; 103: 571-584

160 Mukherjee S, Bhattacharya RK, Roy M. Targeting protein kinase C (PKC) and telomerase by phenethyl isothiocyanate (PEITC) sensitizes PC-3 cells towards chemotherapeutic drug-induced apoptosis. J Environ Pathol Toxicol Oncol 2009; 28: 269-282

161 Yuan H, Gong A, Young CY. Involvement of transcription factor Sp1 in quercetin-mediated inhibitory effect on the androgen receptor in human prostate cancer cells. Carcinogenesis 2005; 26: 793-801

162 Huynh H, Nguyen TT, Chan E, Tran E. Inhibition of ErbB-2 and ErbB-3 expression by quercetin prevents transforming growth factor alpha (TGF-alpha)- and epidermal growth factor (EGF)-induced human PC-3 prostate cancer cell proliferation. Int J Oncol 2003; 23: 821-829

163 Aalinkeel R, Bindukumar B, Reynolds JL, Sykes DE, Mahajan SD, Chadha $K C$, Schwartz SA. The dietary bioflavonoid, quercetin, selectively induces apoptosis of prostate cancer cells by down-regulating the expression of heat shock protein 90. Prostate 2008; 68: 1773-1789 
164 Senthilkumar K, Elumalai P, Arunkumar R, Banudevi S, Gunadharini $N D$, Sharmila G, Selvakumar K, Arunakaran J. Quercetin regulates insulin like growth factor signaling and induces intrinsic and extrinsic pathway mediated apoptosis in androgen independent prostate cancer cells (PC-3). Mol Cell Biochem 2010; 344: 173-184

$165 \mathrm{Kim}$ YH, Lee DH, Jeong JH, Guo ZS, Lee YJ. Quercetin augments TRAILinduced apoptotic death: involvement of the ERK signal transduction pathway. Biochem Pharmacol 2008; 75: 1946-1958

166 Pratheeshkumar P, Budhraja A, Son YO, Wang X, Zhang Z, Ding S, Wang L, Hitron A, Lee JC, Xu M, Chen G, Luo J, Shi X. Quercetin inhibits angiogenesis mediated human prostate tumor growth by targeting VEGFR2 regulated AKT/mTOR/P70S6K signaling pathways. PLoS One 2012; 7: 47516

167 Sarkar SM. Isolation from argemone oil of dihydrosanguinarine and sanguinarine; toxicity of sanguinarine. Nature 1948; 162: 265

168 Adhami VM, Aziz MH, Reagan-Shaw SR, Nihal M, Mukhtar H, Ahmad N. Sanguinarine causes cell cycle blockade and apoptosis of human prostate carcinoma cells via modulation of cyclin kinase inhibitor-cyclincyclin-dependent kinase machinery. Mol Cancer Ther 2004; 3: 933940

169 Sun M, Lou W, Chun JY, Cho DS, Nadiminty N, Evans CP, Chen J, Yue J, Zhou $Q$ Gao AC. Sanguinarine suppresses prostate tumor growth and inhibits survivin expression. Genes Cancer 2010; 1: 283-292

170 Sun M, Liu C, Nadiminty N, Lou W, Zhu Y, Yang J, Evans CP, Zhou Q Gao $A C$. Inhibition of Stat 3 activation by sanguinarine suppresses prostate cancer cell growth and invasion. Prostate 2012; 72: 82-89

171 Wagner H, Horhammer L, Munster R. [On the chemistry of silymarin (silybin), the active principle of the fruits from Silybum marianum (L.) Gaertn. (Carduus marianus L.)]. Arzneim Forsch 1968; 18: 688696

172 Tyagi A, Agarwal C, Agarwal R. Inhibition of retinoblastoma protein (Rb) phosphorylation at serine sites and an increase in Rb-E2F complex formation by silibinin in androgen-dependent human prostate carcinoma LNCaP cells: role in prostate cancer prevention. Mol Cancer Ther 2002; 1: 525-532

173 Thelen P, Jarry H, Ringert RH, Wuttke W. Silibinin down-regulates prostate epithelium-derived Ets transcription factor in LNCaP prostate cancer cells. Planta Med 2004; 70: 397-400

174 Thelen P, Wuttke W, Jarry H, Grzmil M, Ringert RH. Inhibition of telomerase activity and secretion of prostate specific antigen by silibinin in prostate cancer cells. J Urol 2004; 171: 1934-1938

175 Sharma Y, Agarwal C, Singh AK, Agarwal R. Inhibitory effect of silibinin on ligand binding to erbB1 and associated mitogenic signaling, growth, and DNA synthesis in advanced human prostate carcinoma cells. Mol Carcinog 2001; 30: 224-236

176 Roy S, Kaur M, Agarwal C, Tecklenburg M, Sclafani RA, Agarwal R. p 21 and p 27 induction by silibinin is essential for its cell cycle arrest effect in prostate carcinoma cells. Mol Cancer Ther 2007; 6: 2696-2707

177 Agarwal C, Tyagi A, Kaur M, Agarwal R. Silibinin inhibits constitutive activation of Stat3, and causes caspase activation and apoptotic death of human prostate carcinoma DU145 cells. Carcinogenesis 2007; 28: $1463-1470$

178 Deep G, Singh RP, Agarwal C, Kroll DJ, Agarwal R. Silymarin and silibinin cause G1 and G2-M cell cycle arrest via distinct circuitries in human prostate cancer PC3 cells: a comparison of flavanone silibinin with flavanolignan mixture silymarin. Oncogene 2006; 25: 10531069

179 Zi X, Zhang J, Agarwal R, Pollak M. Silibinin up-regulates insulin-like growth factor-binding protein 3 expression and inhibits proliferation of androgen-independent prostate cancer cells. Cancer Res 2000; 60: $5617-5620$

180 Deep G, Gangar SC, Agarwal C, Agarwal R. Role of E-cadherin in antimigratory and antiinvasive efficacy of silibinin in prostate cancer cells. Cancer Prev Res (Phila) 2011; 4: 1222-1232

181 Wu K, Zeng J, Li L, Fan J, Zhang D, Xue Y, Zhu G, Yang L, Wang X, He D. Silibinin reverses epithelial-to-mesenchymal transition in metastatic prostate cancer cells by targeting transcription factors. Oncol Rep 2010; 23: 1545-1552

182 Kavitha CV, Deep G, Gangar SC, Jain AK, Agarwal C, Agarwal R. Silibinin inhibits prostate cancer cells- and RANKL-induced osteoclastogenesis by targeting NFATc1, NF-kappaB, and AP-1 activation in RAW264.7 cells. Mol Carcinog 2014; 53: 169-180

183 Singh RP, Raina K, Sharma G, Agarwal R. Silibinin inhibits established prostate tumor growth, progression, invasion, and metastasis and suppresses tumor angiogenesis and epithelial-mesenchymal transition in transgenic adenocarcinoma of the mouse prostate model mice. Clin Cancer Res 2008; 14: 7773-7780

184 Flaig TW, Glode M, Gustafson D, van Bokhoven A, Tao Y, Wilson S, Su LJ, Li Y, Harrison G, Agarwal R, Crawford ED, Lucia MS, Pollak M. A study of high-dose oral silybin-phytosome followed by prostatectomy in patients with localized prostate cancer. Prostate 2010; 70: 848-855

185 Zhang Y, Talalay P, Cho CG, Posner GH. A major inducer of anticarcinogenic protective enzymes from broccoli: isolation and elucidation of structure. Proc Natl Acad Sci U S A 1992; 89: 2399-2403

186 Cho SD, Li G, Hu H, Jiang C, Kang KS, Lee YS, Kim SH, Lu J. Involvement of c-Jun N-terminal kinase in G2/M arrest and caspase-mediated apoptosis induced by sulforaphane in DU145 prostate cancer cells. Nutr Cancer 2005; 52: 213-224

187 Wiczk A, Hofman D, Konopa G, Herman-Antosiewicz A. Sulforaphane, a cruciferous vegetable-derived isothiocyanate, inhibits protein synthesis in human prostate cancer cells. Biochim Biophys Acta 2012; 1823: 1295-1305

188 Chiao JW, Chung FL, Kancherla R, Ahmed T, Mittelman A, Conaway CC. Sulforaphane and its metabolite mediate growth arrest and apoptosis in human prostate cancer cells. Int J Oncol 2002; 20: 631-636

189 Clarke JD, Hsu A, Yu Z, Dashwood RH, Ho E. Differential effects of sulforaphane on histone deacetylases, cell cycle arrest and apoptosis in normal prostate cells versus hyperplastic and cancerous prostate cells. Mol Nutr Food Res 2011; 55: 999-1009

190 Yao H, Wang H, Zhang Z, Jiang BH, Luo J, Shi X. Sulforaphane inhibited expression of hypoxia-inducible factor-1alpha in human tongue squamous cancer cells and prostate cancer cells. Int J Cancer 2008; 123: $1255-1261$

191 Hahm ER, Chandra-Kuntal K, Desai D, Amin S, Singh SV. Notch activation is dispensable for $\mathrm{D}$, L-sulforaphane-mediated inhibition of human prostate cancer cell migration. PLoS One 2012; 7: 44957

192 Myzak MC, Tong P, Dashwood WM, Dashwood RH, Ho E. Sulforaphane retards the growth of human $\mathrm{PC}-3$ xenografts and inhibits HDAC activity in human subjects. Exp Biol Med (Maywood) 2007; 232: 227234

193 Pagola S, Benavente A, Raschi A, Romano E, Molina MA, Stephens PW. Crystal structure determination of thymoquinone by high-resolution X-ray powder diffraction. AAPS PharmSciTech 2004; 5: 28

194 Kaseb AO, Chinnakannu K, Chen D, Sivanandam A, Tejwani S, Menon M, Dou QP, Reddy GP. Androgen receptor and E2F-1 targeted thymoquinone therapy for hormone-refractory prostate cancer. Cancer Res 2007; 67: 7782-7788

195 Koka PS, Mondal D, Schultz M, Abdel-Mageed AB, Agrawal KC. Studies on molecular mechanisms of growth inhibitory effects of thymoquinone against prostate cancer cells: role of reactive oxygen species. Exp Biol Med (Maywood) 2010; 235: 751-760

196 Yi T, Cho SG, Yi Z, Pang X, Rodriguez M, Wang Y, Sethi G, Aggarwal BB, Liu $M$. Thymoquinone inhibits tumor angiogenesis and tumor growth through suppressing AKT and extracellular signal-regulated kinase signaling pathways. Mol Cancer Ther 2008; 7: 1789-1796

197 Rowe EJ, Orr JE, Uhl AH, Parks LM. Isolation of oleanolic acid and ursolic acid from Thymus vulgaris, L. J Am Pharm Assoc Am Pharm Assoc 1949; 38: 122-124

198 Zhang Y, Kong C, Zeng Y, Wang L, Li Z, Wang H, Xu C, Sun Y. Ursolic acid induces PC-3 cell apoptosis via activation of JNK and inhibition of Akt pathways in vitro. Mol Carcinog 2010; 49: 374-385

199 Zhang YX, Kong CZ, Wang LH, Li JY, Liu XK, Xu B, Xu CL, Sun YH. Ursolic acid overcomes $\mathrm{Bcl}$-2-mediated resistance to apoptosis in prostate cancer cells involving activation of JNK-induced Bcl-2 phosphorylation and degradation. J Cell Biochem 2010; 109: 764-773

200 Shanmugam MK, Ong TH, Kumar AP, Lun CK, Ho PC, Wong PT, Hui KM, Sethi $G$. Ursolic acid inhibits the initiation, progression of prostate cancer and prolongs the survival of TRAMP mice by modulating proinflammatory pathways. PLoS One 2012; 7: 32476

201 Shanmugam MK, Manu KA, Ong TH, Ramachandran L, Surana R, Bist $P$, Lim LH, Kumar AP, Hui KM, Sethi G. Inhibition of CXCR4/CXCL12 signaling axis by ursolic acid leads to suppression of metastasis in transgenic adenocarcinoma of mouse prostate model. Int J Cancer 2011; 129: 1552-1563

202 Kondo M, MacKinnon SL, Craft CC, Matchett MD, Hurta RA, Neto CC. Ursolic acid and its esters: occurrence in cranberries and other Vaccinium fruit and effects on matrix metalloproteinase activity in DU145 prostate tumor cells. J Sci Food Agric 2011; 91: 789-796 